$A L .2 .2000-100$

C.2

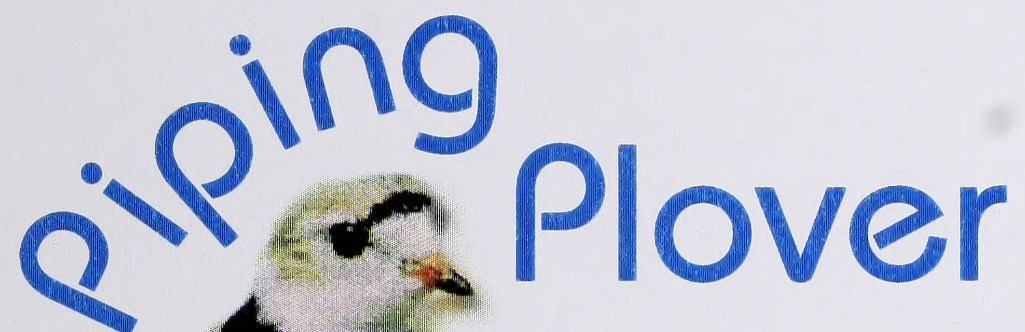

Habitat Classification
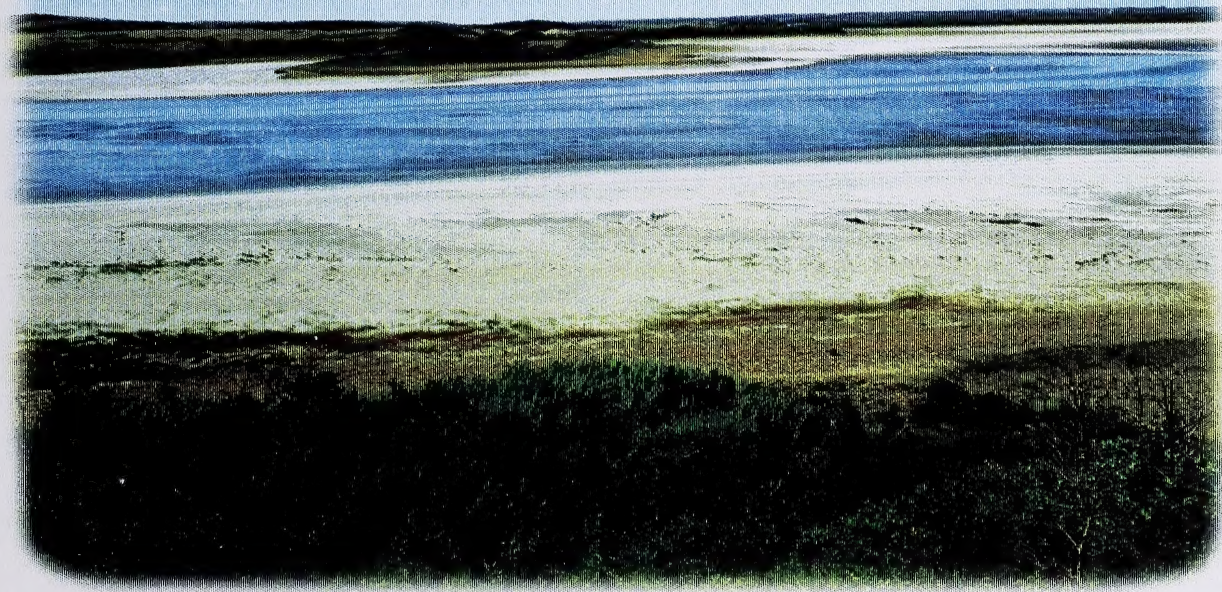

and Inventory for Selected Parkland Region Lakes

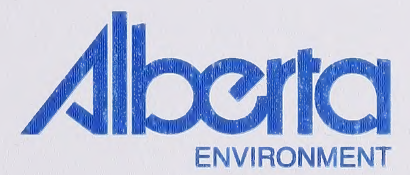




\title{
PIPING PLOVER HABITAT CLASSIFICATION \\ AND INVENTORY FOR \\ SELECTED PARKLAND REGION LAKES
}

\author{
One Of Two Reports \\ Documenting Habitat Suitability \\ for \\ Selected Piping Plover Lakes \\ in
}

The Parkland and Grassland Natural Regions

Alberta Environment

Land and Forest Service

Resource Data Division

Ecosystem Data Section

R. E. Wells and B. J. Cornish

June 1999 


\section{ACKNOWLEDGEMENTS}

The Piping Plover habitat classification and inventory of the Reflex, Killarney and Rockeling Bay/Rider lakeshore areas was conducted by the Ecosystem Data Branch, Resource Data Division of Alberta Environmental Protection.

The authors wish to acknowledge the contributions made by the following persons to the successful completion of this report:

- Dan Ferguson for managing and monitoring acquisition of the necessary aerial photography and for helpful suggestions with regard to timing of the photography.

- Linda Smith for preparation of the aerial photo mosaics used to compile the habitat maps.

- Lucy Faferek for work in ARC/INFO to produce clean, final digital maps merged with polygon attribute data and for initial work to prepare habitat suitability diagram maps.

- Bob Sleep for work in ArcView to prepare the final habitat suitability diagram maps.

- Ken Dutchak for additional help with the graphics present in the report.

- $\quad$ Alberta Fish and Wildlife field staff for helpful on-site assistance with regard to plover nesting requirements and activities on a number of lakes.

- Paul Goossen, Canadian Wildlife Service, for information on plover population studies, helpful suggestions and guidance with regard to additional resource information and contacts during the project.

- Members of the Plover Ad Hoc Committee for information and helpful interaction during the project.

- Special thanks also to Gwen Edge, Graphic Designer, Alberta Environment, for the report cover design. 


\section{TABLE OF CONTENTS}

Page

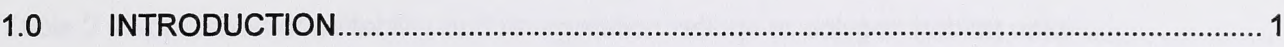

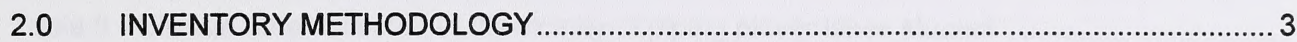

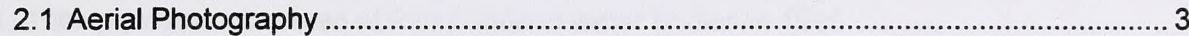

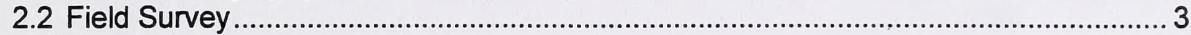

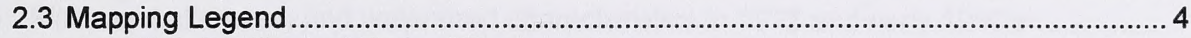

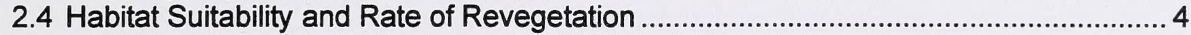

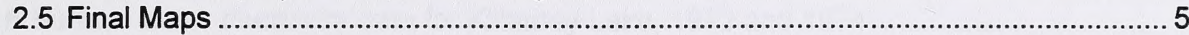

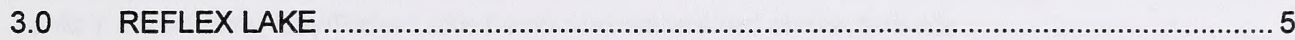

3.1 Location and General Description ..................................................................... 5

3.2 Lake and Drainage Basin Characteristics ......................................................... 6

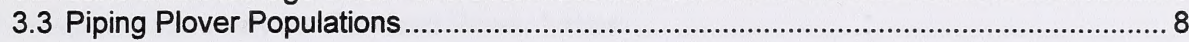

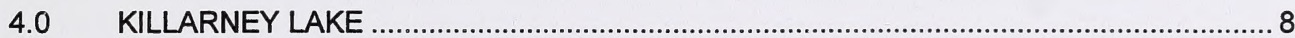

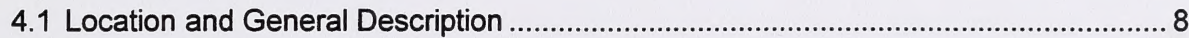

4.2 Lake and Drainage Basin Characteristics ............................................................. 9

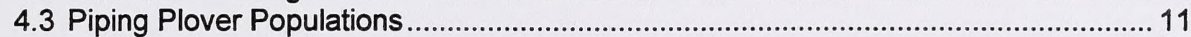

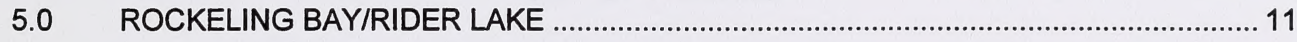

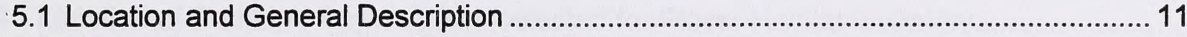

5.2 Lake and Drainage Basin Characteristics ....................................................... 12

5.3 Piping Plover Populations ................................................................................. 14

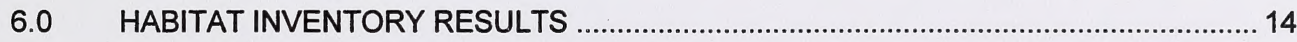

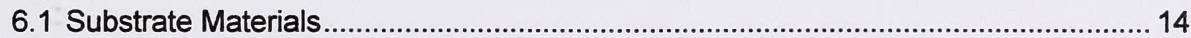

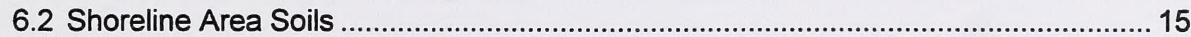

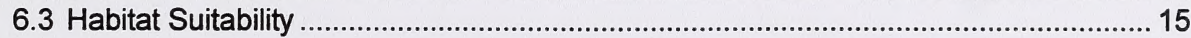

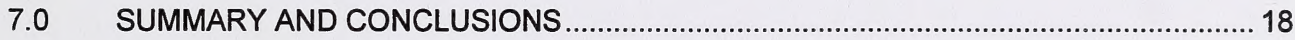

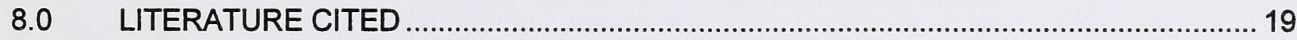

APPENDIX A - Adult Piping Plover at Four Parkland Lakes .................................................. 22

APPENDIX B - Diagram Maps for Plover Habitat Suitability .................................................. 24

APPENDIX C - Generalized Piping Plover Map Legend ..................................................... 28 


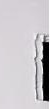

1

1

1

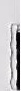

(

\&

1

1 


\section{LIST OF TABLES}

Table 1 - Location of Parkland Region lakes selected for plover habitat mapping 1

Table 2 - Application of suitability and revegetation ratings to polygon habitat units 4

Table 3 - Climate data collected in the vicinity of piping plover lakes studied 6

Table 4 - Piping plovers observed at four parkland water bodies in 1995 8

Table 5 - Killarney Lake basin and watershed characteristics in 1972 and early 1990's 10

Table - 6 Surface water chemistry data for Killarney Lake, 1972 and 1974 10

Table 7 - Rockeling Bay/Rider Lake basin and watershed characteristics 12

Table 8 - Surface water chemistry data for Rockeling (Rockland) Bay, 1980 and 1993 13

Table 9 - Map unit summary for Parkland Plover Lakes 16

\section{LIST OF FIGURES}

Figure 1 - Location of Parkland Region lakes selected for Plover Habitat Inventory. 2

Figure 2 - Shoreline Habitat Distribution 17 



\section{PIPING PLOVER HABITAT CLASSIFICATION AND INVENTORY FOR SELECTED PARKLAND REGION LAKES}

\subsection{INTRODUCTION}

The piping plover (Charadrius melodus) is a small plump shorebird with sandy-coloured upperparts, a diagnostic bill shape and distinctive head and breast patterns. They were hunted close to extinction in the late 1800 s and early 1900 s. Although recovering somewhat under the Migratory Birds Convention Act, the species began to decline again in the 1940s (Haig and Oring 1985), and is now ranked as endangered (COSEWIC 1998).

This bird is found typically on sandy or gravelly beaches of saline lakes. Habitat requirements include a dry, sparsely vegetated backshore area above the high water line for nesting, and wet shoreline areas close to water's edge for feeding (Wershler and Wallis 1986). Because of the requirement for virtually non-vegetated gravelly nesting areas, only certain types of water bodies provide suitable habitat. Two factors, high salinity of the water and fluctuating water levels, prevent the establishment of vegetation and in the long-term ensure the maintenance of the barren sandy or gravelly areas along the shorelines for nesting (Wershler 1988)

In Alberta, the species breeds at lakes, ponds and rivers in the Parkland and Grassland Natural Regions, as far north as the North Saskatchewan River and south to the Oldman and South Saskatchewan rivers (Semenchuk 1992).

In response to a request from Alberta Fish and Wildlife Division, the Alberta Resource Data Division began a study to collect baseline plover habitat Information at lakes that support nesting piping plover. These data would be useful in documenting on-going habitat changes and impacts on plover numbers. Specific objectives were to:

1. Map substrate distribution, reflecting presence of gravels at the surface and the rate at which vegetation is expected to become established.

2. Establish preliminary habitat suitability ratings for piping plover nesting.

Based on their significance to piping plovers in Alberta, ten key lakes were selected for baseline habitat mapping. In the Parkland Region these included West Reflex Lake (west of the $4^{\text {th }}$ Meridian), Killarney Lake (along with a small adjacent pond), and Rockeling (or Rockland) Bay with 'Rider Lake' (adjacent to Buffalo Lake). In the Grassland Region, Little Fish, Handhills, Dowling, Chain Lake \#4, Chappice and Sam lakes were selected for study.

This report presents the results of the habitat research carried out at Parkland Region waterbodies in 1995 (Table 1, Fig. 1). Habitat mapping results for Little Fish Lake (Wells and Lindberg 1991) and for other lakes in the Grassland Region (Wells and Cornish1999) are presented under separate cover.

Table 1. Location of Parkland Region lakes selected for piping plover habitat mapping.

\begin{tabular}{l|l|l|l}
\hline Site Name & Location & $\begin{array}{l}\text { Map } \\
\text { Sheet }\end{array}$ & Lat./Long. \\
\hline West Reflex Lake & Twp 42, 43, Rge 1, W4M & 73 D/9 & $53^{\circ} 40^{\prime} 110^{\circ} 00^{\prime}$ \\
\hline Killarney Lake & Twp. 41,42, Rge 1, W4M & 73 D/9 & $53^{\circ} 35^{\prime} 110^{\circ} 05^{\prime}$ \\
\hline $\begin{array}{l}\text { Rockeling Bay/ } \\
\text { Rider Lake }\end{array}$ & Twp 41, Rge 20, W4M & 83 A/10 & $\begin{array}{l}52^{\circ} 33^{\prime} 112^{\circ} 48^{\prime} ; \\
52^{\circ} 32^{\prime} 112^{\circ} 46^{\prime}\end{array}$ \\
\hline
\end{tabular}




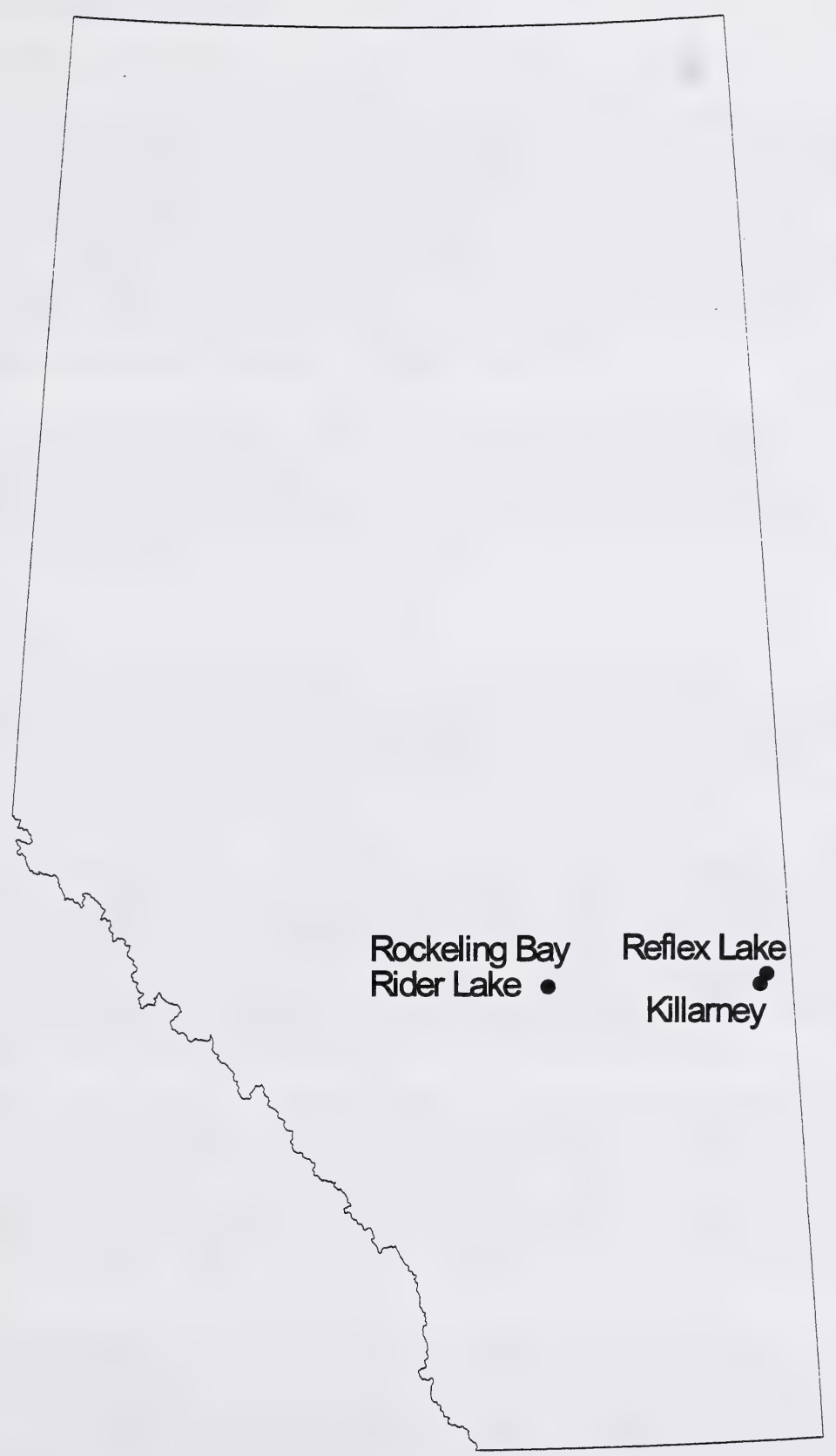

Figure 1 - Location of Parkland Region Lakes Selected for Plover Habitat Inventory 


\subsection{INVENTORY METHODOLOGY}

\subsection{Aerial Photography}

Two sets of black and white aerial photography were flown at different scales in mid June, 1995, for each of the plover lakes described below. One set, at 1:10 000, was used for photo interpretation and field mapping. The second set, at 1:30 000 or 1:40 000 depending on the size of the lake, was used to prepare semi-controlled photo mosaics for enlargement to $1: 10000$ and use as photo-transfer base maps. After the field mapping operation, polygon boundaries and designations were transferred from the 1:10 000 photos to the photo mosaic bases at the same scale. Final plover habitat maps were compiled on the photo mosaics for each lake. Line work from each of these maps was digitized and merged with their polygon attribute data to bring them into the Department's Arc/Info geographic information system.

Acquisition of new aerial photography was scheduled to avoid nest disturbance and to coincide with essentially full shoreline vegetation development (Wells and Lindberg 1991). Because field survey operations could not begin until mid July, after plover fledglings have left nesting sites, air photos had to show ground conditions at full vegetation for accurate location of soil observations. This also allowed enough lead time to obtain the new air photos for preliminary interpretation and field survey.

\subsection{Field Survey}

Field data were collected at soil observation pits located within the stratification provided by preliminary air photo interpretation boundaries. The observation pits were located along transects running from the current lakeshore boundary to the former high water mark. Additional observations were done in order to adequately inventory areas of high substrate material complexity.

Basic site and soil data was collected at each observation site. Site data collected included slope, aspect, surface expression, identification of surficial materials (lacusrine, till, residual, etc.) and contrasting layers if present. Soil profile data collected included: soil horizons, their color, texture, structure, estimated coarse fragment or gravel content, presence of lime and/or soluble salts, and presence of gley features. Kind and amount of surface coarse fragments (gravel, cobbles, stones or boulders) were estimated, and depth to water table was recorded if present within the soil control section $(1.5 \mathrm{~m})$. No soil samples were collected for laboratory analysis.

The first objective of the field inventory was to identify and delineate non-vegetated map units with sufficient gravel content either within the mineral substrate or on the surface to provide plover nesting habitat. The second objective was to estimate the likely rate of revegetation of these map units as indicated by the presence and amount of surface soil salinity observed within the units. The field estimates are necessarily tentative because they are not corroborated by quantitative laboratory data to verify the degree of salinity and sodicity (sodium content) actually present.

Vegetation data collected at each site was essentially physiognomic in nature and is stratified to reflect the time since last major inundation and/or the frequency of inundation. Vegetation covers range from recently exposed, non-vegetated wetlands with shallow water tables adjacent the current lakeshore-to sparsely or partially vegetated wetlands with deeper water tables-to dryer, fully vegetated, upland grass communities-to still higher upland grass and shrub covers (with or without trees). Intermingled with these covers, generally at low to mid lakeshore positions, may be units with "weedy" (Canada thistle, sow thistle, sweet clover) vegetation cover reflecting somewhat dryer but still periodically inundated or saturated moisture conditions. The saturated moisture conditions usually result from a rise in the underlying ground water table. However, saturated conditions may also occur from lateral moisture seepage along a compact or clay textured layer at shallow depth (less than $1 \mathrm{~m}$ ) under a coarser-textured surface layer. 


\subsection{Mapping Legend}

The mapping legend (Appendix $C$ ) is designed to show map unit components that reflect the interrelationships among soil parent origin and texture, soil profile development, salinity, drainage conditions, depth to and fluctuations of water table, and the kind and rate of vegetation growth. The mapping legend built for the habitat inventory of Little Fish Lake (Wells and Lindberg 1991) was extended and generalized for inventory of other plover lakes in both the Parkland and Grassland Natural Regions. As it stands, the current legend is not a full-fledged ecological mapping legend. Its emphasis is on identification and characterization of substrate materials with only general or physiognomic description of vegetation cover. With additional work to identify and integrate vegetation community types within map units, the legend should also reflect further differences between plover habitats between the two natural regions and possibly be more helpful in estimating rate of revegetation.

Even at a scale of 1:10 000, many polygons are made up of more than one map unit component and have to be shown as complexes of primary, secondary and possibly tertiary components. The relative amounts of each component are indicated in decreasing order of abundance in the polygon database (or on the hardcopy maps as indicated either by decreasing order or by $I, I /$ slashes) as follows:

$$
\text { Primary }(\geq 55 \%) / \text { Secondary }(20-45 \%) / / \text { Tertiary ( } \leq 20 \%) \text {. }
$$

A primary component present by itself is understood as occupying greater than $90 \%$ of the polygon area. Primary and Secondary components present indicate proportions of $55-70 \%$ and $20-45 \%$, respectively. Primary and Tertiary components present indicate $80-90 \%$ and $10-20 \%$ coverage, respectively.

Note that because the generalized legend in Appendix $C$ also applies to shoreline areas mapped at lakes in the Grassland region, a few of the units do not occur in the inventoried Parkland plover lakes reported here.

\subsection{Habitat Suitability and Rate of Revegetation}

Plover habitat suitability and revegetation ratings discussed below are shown in the general legend in Appendix C, in the Figure 2 bar graph, and their distribution is displayed on the color diagram maps for each lake in Appendix $B$.

\subsubsection{Suitability}

The model used for application of suitability and revegetation ratings to polygon units found to have some habitat potential is listed in Table 2.

Table 2 - Application of suitability and revegetation ratings to polygon habitat units.

\begin{tabular}{ccccccc}
\hline \multicolumn{2}{c}{ Primary } & \multicolumn{2}{c}{ Secondary } & \multicolumn{2}{c}{ Tertiary } & $\begin{array}{c}\text { Polygon } \\
\text { Rating }\end{array}$ \\
\hline HS & RV & HS & RV & HS & RV & \\
\hline S & N & - & - & $\pm S$ & \pm N,S & SN \\
S & S & - & - & $\pm S$ & $\pm N, S$ & SS \\
S & N & U & N,S & - & - & MN \\
S & S & U & N,S & - & - & MS \\
U & S & - & - & S & S & MS \\
U & N & - & - & S & N & MN* \\
U & N & S & S & - & - & MS \\
U & N & S & S & S & S,N & MS \\
U & N & S & N & - & - & MN \\
U & N & S & N & S & N,S & MN \\
& & & & & &
\end{tabular}




\begin{tabular}{lllllll}
$M$ & $N$ & - & - & - & - & $M N$ \\
$M$ & $S$ & - & - & - & - & $M S$ \\
$M$ & $N$ & $S$ & $N$ & - & - & $M N$ \\
$M$ & $S$ & $S$ & $S$ & - & - & $M S$ \\
\hline
\end{tabular}

*Non-vegetated units

Ratings of Suitable are assigned to each map polygon based on the dominant presence (greater than $50 \%$ of the polygon area) of non-vegetated map unit components with fine $(0.2-0.5 \mathrm{~cm})$ and medium $(0.5-2 \mathrm{~cm})$ gravel in and/or on a surface soil layer. Units with fine lag surface gravel ( $\mathrm{LSg}$, LSgs units) are separated from those with a gravelly upper layer (LG, LGs units) because these surface gravels tend to be ephemeral and may not remain in place during any major future inundation.

Polygons with a Suitable primary component and an Unsuitable secondary component (e.g. LG/LSv) receive a Marginal rating. On the other hand, a non-vegetated polygon having an Unsuitable primary component and Suitable secondary or tertiary components (e.g. LSs/LGs or LSs//LGs) also receives a Marginal rating (See asterisked combinations in above list). This is because absence of vegetation allows plovers to make use of any suitable areas within the polygon, provided that distance to water is not too great.

Non-vegetated gravelly units (EG, EGs) also receive a marginal rating because active wind deposition during the nesting season may bury nesting sites with sand.

\subsubsection{Revegetation}

Rate of revegetation rating is based on the on-site, observed presence of surface and subsoil salinity and its assumed effect on vegetation growth. Because no soil samples were taken to get quantitative estimates of the amount and kind of soluble salts present, only two ratings were used, Slow and Normal, based on visual estimates of low or absent versus moderate to severe surface salt presence. Slowly vegetated unsuitable areas were also mapped separately from normally vegetated areas. This is because of their different potential, especially those with gravel, as possible future nesting sites, either after future inundation and exposure, or for treatment for habitat improvement.

\subsection{Final Maps}

Final habitat maps are supplied in digital format for presentation at 1:10 000 in cleaned and merged spatial polygon and attribute databases in Arc/Info .E00 file format. They are registered to the Alberta digital 1:20 000 base map files in UTM projection and NAD 27 datum referenced. These data are supplied on CD-ROM disk together with a digital copy of this report in Microsoft Word format. Black and white copies of the final working copy maps made from annotated photo mosaics of each of the three lakes are on file in the Regional Alberta Environment office, Fish and Wildlife Division at Red Deer, Alberta.

\subsection{REFLEX LAKE}

\subsection{Location and General Description}

West Reflex Lake, known locally as Salt Lake, is one of a series of saline lakes extending from eastern Alberta into Saskatchewan. This permanent, hypersaline lake straddles the AlbertaSaskatchewan boundary near Chauvin, $40 \mathrm{~km}$ northeast of Provost (Fig. 1). The Alberta portion occupies parts of Townships 42-43, Range 1, west of the $4^{\text {th }}$ Meridian, and is included within the Central Parkland Natural Subregion (Achuff 1994). 
Reflex Lake is classed as primary piping plover breeding habitat, since it appears to provide reliable nesting habitat regardless of climatic fluctuations (Wershler 1992). This is one of the most important piping plover nesting habitats in Alberta (Wallis 1990).

Adjacent to the lake basin there are both private and crown lands. Crown lands include the lakebed and the southeast quarter of Section 36 - Twp $42-$ Rge 1, W4M. Primary utilization includes recreation, grazing, annual crops and hay crops. Off-road motor vehicles are occasionally a problem, and there is some recreational cottage development in the area (Nature Conservancy 1990).

\subsection{Lake and Drainage Basin Characteristics}

\subsubsection{Climate}

Long-term climate data are available from a station at Kinsella Ranch near Wainwright, about 55 $\mathrm{km}$ to the west at an elevation of $705 \mathrm{~m}$ above sea level (asl) (Table 3; Environ. Canada 1993). These data, collected from 1962 to 1990 , are summarized below.

- The mean daily temperature varies from $-15^{\circ} \mathrm{C}$ to $+17^{\circ} \mathrm{C}$.

- The annual mean temperature is $2.3^{\circ} \mathrm{C}$.

- The wettest months are June and July, and the driest month is February. The mean total annual precipitation is $428 \mathrm{~mm}$, of which an average of $319 \mathrm{~mm}$ (about $75 \%$ ) falls as rain.

Table 3. Climate data collected at stations in the vicinity of piping plover lakes studied in the Parkland Region (Environ. Canada 1993).

\begin{tabular}{c|c|c|c|c|c}
\hline $\begin{array}{c}\text { Climate } \\
\text { Station }\end{array}$ & $\begin{array}{c}\text { Location } \\
\text { (Lat./Long.); } \\
\text { Elevation asl }\end{array}$ & $\begin{array}{c}\text { Nearby Piping } \\
\text { Plover Habitats }\end{array}$ & $\begin{array}{c}\text { Total } \\
\text { Precip. } \\
\text { (mm) }\end{array}$ & $\begin{array}{c}\% \text { as } \\
\text { rain }\end{array}$ & $\begin{array}{c}\text { Mean } \\
\text { Annual } \\
\text { Temp. } \\
\text { ( }{ }^{\circ} \text { ) }\end{array}$ \\
\hline $\begin{array}{c}\text { Kinsella Ranch } \\
\text { near Wainwright }\end{array}$ & $\begin{array}{c}5300 \mathrm{~N}, \\
11131 \mathrm{~W} ; \\
705 \mathrm{~m}\end{array}$ & $\begin{array}{c}\text { West Reflex } \\
\text { Lake; } \\
\text { Killarney Lake }\end{array}$ & 428 & 75 & 2.3 \\
\hline Red Deer & $\begin{array}{c}5211 \mathrm{~N} \\
11354 \mathrm{~W} ; \\
905 \mathrm{~m}\end{array}$ & $\begin{array}{c}\text { Rockeling Bay } \\
\text { /Rider Lake }\end{array}$ & 470 & 76 & 2.6 \\
\hline
\end{tabular}

\subsubsection{Bedrock Geology, Landforms and Surficial Materials}

West Reflex Lake is part of the Eastern Alberta Plain (Pettapiece 1986). The lake is included within the Ribstone Plain Ecodistrict (Strong and Thompson 1995).

The bedrock underlying the lands surrounding the park consists of a sequence of sedimentary rocks of Upper Cretaceous age (Wyatt et al 1944, Carlson and Topp 1971). Closest to the surface around most of the perimeter of the lake is the Birch Lake Formation, consisting of buff to yellow-coloured sandstone and some interbedded shale. An older formation, the Grizzly Bear marine shale formation, underlies areas north of Reflex Lake (Wyatt et al 1944). A major preglacial valley runs west of Reflex Lake (Hackbarth 1975).

The uplands surrounding Reflex Lake are primarily rolling to hilly glacial deposits or reworked glacial deposits associated with the most recent Laurentide glaciation. Most common are sandy glaciofluvial deposits, primarily kame moraine, deposited by glacial meltwater near the ice front (Bayrock 1967, Wyatt et al 1944). An area of eolian deposits, formed on top of glacial till, occurs southeast of the lake (Thorpe and Godwin 1993). 


\subsubsection{Hydrography}

Reflex Lake is within the North Saskatchewan River drainage basin. The watershed area contributing runoff to the lake has been estimated at $69.2 \mathrm{~km}^{2}$ (Deboer 1995). The lake has no apparent outflow.

Hydrologic measurements are unavailable, but area - capacity relationships were calculated and lake size simulated based on specific water level increments. The size of Reflex Lake, based on estimated month end water levels from 1972 to 1993 , is predicted to range from about 450 ha to about 1000 ha (Deboer 1995).

Several permanent seepage springs can be found principally in backshore areas in the southwestern corner of the lake. These saline springs flow even during extended periods of drought (Nature Conservancy of Canada 1990).

\subsubsection{Water Quality}

This is a permanent hypersaline lake (Wallis 1990). No detailed water quality data are available, however.

\subsubsection{Vegetation}

No emergent or submergent aquatic vegetation grows in the lake (Nature Conservancy of Canada 1990). The vegetation types occurring around the lake include sparse alkali shoreline, saline springs, grassland / meadows, tall shrub communities, balsam poplar woods and aspen woods. These types can be found in a sequence extending outward from the abandoned lake shoreline to surrounding uplands (Wallis 1990).

Vegetation along the sandy or gravelly nearshore is sparse to non-existent. Plant species which can be found intermittently along the foreshore/nearshore areas include: on wetter areas western sea-blite (Suaeda calceoliformis), Nevada bulrush (Scirpus nevadensis), three-square rush (Scirpus pungens), and seaside arrow-grass (Triglochin maritimum); and on somewhat drier nearshore sites - salt grass (Distichlis stricta), scratch grass (Muhlenbergia asperifolia), alkali cord grass (Spartina gracilis), western wheat grass (Agropyron smithii), foxtail barley (Hordeum jubatum) and wire rush (Juncus balticus) (Wallis 1990).

Vegetation near the saline springs is very diverse, including many of the halophytic (salt-tolerant) species mentioned above, and others such as rayless aster (Aster brachyactis), creeping spikerush (Eleocharis palustris), and several rare plants (Nature Conserv. of Canada 1990).

Although the vegetation types along shoreline areas are floristically very different from the uplands, some species may overlap, and an understanding of adjacent upland community types may help explain relationships within the nearshore zones. A detailed description of typical native vegetation of aspen woodland is given in Moss (1932). Much of the native vegetation in the parkland has been converted to cultivated cropland, however (Wallis 1987).

A tall shrub community dominated by willows (Salix spp.), water birch (Betula occidentalis), and sometimes silverberry (Elaeagnus commutata) forms a band around the highest parts of the abandoned lakeshore (Nature Conservancy of Canada 1990). On somewhat higher ground than this shrub community, balsam poplar (Populus balsamifera) woods occur on the moderately welldrained areas. This in turn gives way to the mosaic of aspen poplar (Populus tremuloides) woods, shrubbery and grasslands occurring in the drier uplands.

Upland shrub communities on the kame moraine are dominated by saskatoon (Amelanchier alnifolia), pincherry (Prunus pensylvanica), chokecherry (Prunus virginiana), silverberry, rose (Rosa spp), and buckbrush (Symphoricarpos occidentalis) (Nature Conservancy of Canada 

1990). Grasslands consist primarily of northern wheat grass (Agropyron dasystachyum), june grass (Koeleria macrantha), western porcupine grass (Stipa curtiseta) and spear grass (Stipa comata) along with a variety of forbs.

\subsection{Piping Plover Populations}

The population of adult piping plovers observed at this lake ranges from 12 to $46+$, based on data from 1986 to 1996 (Prescott 1997; Bjorge and Murphy 1997; Appendix A). (Data collection methods and survey coverage varied between years, however). In 1995, the year substrate data were collected at this lake, a total of 37 adults were observed during June surveys (Prescott 1997). That year, a total of 16 nests with eggs or young were also recorded (ANHIC 1998).

Table 4. Piping plovers observed at four parkland region water bodies in Alberta in 1995.

\begin{tabular}{lcc}
\hline LAKE & Adults $^{* 1}$ & $\begin{array}{c}\text { Nests } \\
\text { with eggs } \\
\text { or } \\
\text { young }\end{array}$ \\
\hline $\begin{array}{l}\text { West Reflex } \\
\text { Lake }\end{array}$ & 37 & 16 \\
\hline Killamey Lk. & 40 & 24 \\
\hline Rockeling Bay & 13 & 1 \\
\hline Rider Lake & 6 & 1 \\
\hline
\end{tabular}

*Source: Prescott 1997

** Source: ANHIC 1998

${ }^{1}$ Breeding status unknown;

\subsection{KILLARNEY LAKE}

\subsection{Location and General Description}

Killarney Lake is a permanent, moderately saline lake located in the M.D. of Wainwright, south of Chauvin and about $25 \mathrm{~km}$ northeast of Provost (Fig. 1). The lake occupies parts of Townships 42 (primarily) and 41, Range 1, west of the $4^{\text {th }}$ Meridian. It is included within the Central Parkland Natural Subregion (Achuff 1994).

This lake has been described as less productive for piping plovers than some other lakes because of more restricted nesting habitat or more temporary feeding habitat (Wershler 1990). An adjacent series of shallow waterbodies west of Killarney Lake (here called 'Arvid Project Pond') also provides potential for plover habitat (A. Murphy, pers. comm.; see memo May 31, 1996 to Russ).

Lands within the lake watershed include both private and crown lands, and are utilized for recreation, grazing, annual crops and hay crops. The south end of the lake is part of Dillberry Lake Provincial Park. 



\subsection{Lake and Drainage Basin Characteristics}

\subsubsection{Climate}

Long-term climate data are available from Kinsella Ranch, near Wainwright, at an elevation of $705 \mathrm{~m}$ (Environ. Canada 1993). These are summarized above (Table 3; Section 3.2.1).

\subsubsection{Bedrock Geology, Landforms and Surficial Materials}

Bedrock formations underlying the area are of Upper Cretaceous age, consisting of thickbedded sandstone and shales (Green 1972) belonging to the Pale Beds Formation. The upper parts contain light-coloured bentonite, which if exposed makes soils very sticky when wet and very hard with many cracks when dry.

Killarney Lake covers parts of two ecodistricts - Ribstone Plain and Provost Plain (Strong and Thompson 1995). In the immediate vicinity of Killarney Lake, parent materials are primarily glaciofluvial, glaciolacustrine, morainal and recent lacustrine. Glaciofluvial deposits predominate, especially east and northwest of the lake. These are kame moraine deposits composed of sand to gravelly sand, with small pockets of gravel and scattered lenses of glacial till. The flat valley containing Killarney Lake is composed of glaciofluvial outwash sand. Some glaciolacustrine deposits, consisting of sands and some silt accumulated in proglacial lakes, are present northeast of the lake. Hummocky moraine occurs south of the lake, while recent lacustrine deposits are associated with Killarney Lake shoreline and lowlands to the west (Renewable Resources 1974, Meijer and Karpuk in prep).

The terrain surrounding Killarney Lake is characterized by slopes of 0 to $5 \%$, except in the till deposits to the south where slopes are 5 to 10\% (Renewable Resources 1974). The area can be described as fairly level to undulating with some local knob and kettle relief marked by pothole lakes. Elevation of Killarney Lake is about $646 \mathrm{~m}$.

\subsubsection{Hydrography}

Like Reflex Lake, Killarney Lake lies within the North Saskatchewan River drainage basin. There is no surface outflow. Surface inflow is from the Arvid Project Pond to the west, which is artificially regulated by a control structure. The control structure was built in 1970 for the purpose of creating waterfowl habitat on the smaller waterbody and to prevent the formation of alkali flats (Renewable Resources 1994). Concerns have been expressed about the negative impact of this control structure on long-term maintenance of productive plover feeding and nesting habitat, especially within the small delta of the inlet (Wallis 1990).

At full surface level (FSL), the lake is estimated to be $5.7 \mathrm{~km}^{2}$ in area, including the adjacent Arvid Project Pond, which is contiguous with Killarney Lake at flood levels (A. Murphy pers. comm.; see summary sheet for Killarney). The lake has a maximum depth of $5.0 \mathrm{~m}$, and shoreline length of $13 \mathrm{~km}$ (Table 5). In 1974, the lake surface area was $483 \mathrm{ha}\left(4.83 \mathrm{~km}^{2}\right)$, with a maximum depth of $4.3 \mathrm{~m}$ and a shoreline length of $11.2 \mathrm{~km}$ (Renewable Resources 1974). A bathymetric map was produced in 1974 based on depth measurements taken that year (Alberta Environ., Techn. Services Div. data in Renewable Resources 1974). Lake levels then fell dramatically through the 1980 s and into the early 1990 s. 
Table 5. Killarney Lake basin and watershed characteristics, in 1972 and in the early 1990s (Renewable Resources 1974; A. Murphy, pers. comm.).

\begin{tabular}{l|l|l}
\hline \multicolumn{1}{c|}{ PARAMETER } & 1972 & $\begin{array}{l}\text { 1990s } \\
\text { (estimate) }{ }^{2}\end{array}$ \\
\hline & & \\
\hline Lake surface area (ha) & 483 & \\
\hline Lake basin size $\left(\mathrm{km}^{2}\right.$ & & 5.7 (at FSL*), including Arvid pond) \\
\hline Shoreline length (km) & 11.2 & 13 \\
\hline Modal annual water level decline & & $210 \mathrm{~mm}$ \\
\hline $\begin{array}{l}\text { Modal shoreline exposure (mid } \\
\text { range) }\end{array}$ & & $20 \mathrm{~m}$ \\
\hline $\begin{array}{l}\text { Vertical substrate distribution } \\
\text { (fr/FSL)* }\end{array}$ & & $1.0-4.0 \mathrm{~m}$ \\
\hline Maximum depth (m) & 4.3 & $5.0($ at FSL*) \\
\hline $\begin{array}{l}\text { Plover habitat life expectancy and } \\
\text { return interval }\end{array}$ & & 7 years/20 years \\
\hline Maximum plover habitat width & & $280 \mathrm{~m}$ \\
\hline & & \\
\hline Total watershed drainage area & & $370 \mathrm{~km}^{2}$ \\
\hline
\end{tabular}

${ }^{1}$ Renewable Resources 1974

${ }^{2}$ A. Murphy, pers. comm.

*FSL - full supply level

\subsubsection{Water Quality}

Dillberry Lake is described as having moderately saline sodium bicarbonate-sulphate water (Renewable Resources 1974). Surface water chemistry values taken in 1972 and in 1974 for several parameters are given in Table 6. These data show that the chemistry of the lake is dynamic and varies between years, likely related to factors such as rates of evaporation amd amount of precipitation. However, Govett (1958; in Renewable Resources 1974) concluded that the chemical composition of surrounding surficial deposits is a major control on the chemistry of saline lakes in east-central Alberta.

Table 6. Surface water chemistry data for Killarney Lake, 1972 and 1974 (Renewable Resources 1974)(Concentrations in parts per million).

\begin{tabular}{l|c|c}
\hline Parameter & 1972 & 1974 \\
\hline & & \\
\hline T. Dissolved Solids & 3352 & 3096 \\
\hline Hardness & 106 & 91 \\
\hline Calcium & 12 & 10 \\
\hline Magnesium & 18 & 16 \\
\hline Sulphate & 735 & 580 \\
\hline Chloride & 242 & 237 \\
\hline Alkalinity & 1530 & 1264 \\
\hline Sodium & 1194 & 970 \\
\hline pH & 9.2 & 9.3 \\
\hline
\end{tabular}

\subsubsection{Vegetation}


Vegetation types occurring in the offshore and nearshore areas include aquatic emergents and several halophytic communities. In contrast to Reflex Lake, which supported no aquatic emergent vegetation, several patches of emergents were recorded in 1974 in the northeast and the southwest parts of the lake (Renewable Resources 1974).

A small area of halophytic vegetation surrounds the lake in the abandoned nearshore zone close to the water's edge. Plant species in this saline area consist of several bands of vegetation found in a sequence from wettest to drier soils. These community types are dominated by foxtail barley (Hordeum jubatum), Nuttall's salt-meadow grass (Puccinellia nuttalliana), salt grass (Distichlis stricta), Nevada bulrush (Scirpus nevadensis) and western sea-blite (Suaeda calceoliformis) (Wallis 1990).

The upland vegetation of nearby Dillberry Lake Provincial Park is likely similar to that adjacent to Killarney Lake, and is described in detail in Meijer and Karpuk (in prep.). Balsam poplar woods occur on less well-drained areas associated with lacustrine deposits. The understory consists of water birch (Betula occidentalis) willows (Salix spp.) and red-osier dogwood (Cornus stolonifera). A very diverse forb layer is present in the balsam poplar woods. mosaic of aspen poplar woods, shrubbery and grasslands occurring In the drier sandy upland glaciofluvial and eolian deposits, a mosaic of aspen woods, shrubbery and grasslands occurs.

Tall shrub communities on the upland glaciofluvial deposits (kame moraine) are dominated by saskatoon (Amelanchier alnifolia) and choke cherry (Prunus virginiana) along with low aspen regeneration. Low shrub communities, where silverberry (Elaeagnus commutata), rose (Rosa spp), and buckbrush (Symphoricarpos occidentalis) predominate, occur on somewhat drier aspects or more well-drained soils. Silverberry communities are fairly common on the dry beach ridges surrounding Killarney Lake.

Grasslands are most common on southern aspects. Prominent grass species include western porcupine grass (Stipa curtiseta), slender wheat grass (Agropyron trachycaulum), june grass (Koeleria macrantha), and needle-and-thread (Stipa comata) along with a variety of forbs tolerant of dry conditions.

\subsection{Piping Plover Populations}

The number of piping plovers observed during surveys conducted in the past 10 years has varied from about 8 to 48 (Prescott 1997; Appendix A). In 1995 (the year this habitat study was conducted), 37 adults were observed during June surveys (in Prescott 1997). That year, 16 nests with eggs or young were also recorded (ANHIC 1998). Seven piping plover nests were recorded in 1997 (I. Richardson, pers. comm. in Meijer and Karpuk in prep).

\subsection{ROCKELING BAY/ RIDER LAKE}

\subsection{Location and General Description}

Rockeling (or Rockland) Bay and Rider Lake are interconnected waterbodies just northeast of Buffalo Lake. They are located about 15 to $20 \mathrm{~km}$ eastsoutheast of Bashaw, or about $65 \mathrm{~km}$ east of Lacombe, and occupy parts of several sections in Township 41 Range 20 west of the $4^{\text {th }}$ Meridian. These waterbodies are historical overflow basins which were infrequently filled from Buffalo Lake during flood events (A. Murphy, pers. comm. - memo). However, water levels at Buffalo Lake have been stabilized to enhance recreational opportunities there (Prescott 1997). Mitigative habitat management projects to protect piping plovers nesting at Rockeling Bay/Rider Lake have been proposed.

Historically, Rockeling Bay/Rider Lake have provided reliably productive piping plover nesting habitat, and are classed as primary habitat (Wershler 1992). 



\subsection{Lake and Drainage Basin Characteristics}

\subsubsection{Climate}

Long-term climate data are available from a station at Red Deer, about $55 \mathrm{~km}$ to the southwest. The mean annual temperature at Red Deer is $2.6^{\circ} \mathrm{C}$, and the area receives an average of 470 $\mathrm{mm}$ of annual precipitation, with $76 \%$ falling as rain (Table 5 ).

\subsubsection{Bedrock Geology, Landforms and Surficial Materials}

The uppermost bedrock layer underlying the area is the Horseshoe Canyon Formation. This formation is represented by grey sandstone, bentonitic mudstone and carbonaceous shale, with scattered bentonitic and limestone beds, all of Cretaceous age (Wells and Bentz 1993).

The area around the immediate perimeter of Rockeling Bay/Rider Lake is included in the Buffalo Lake Plain physiographic district of the Eastern Alberta Plains (Pettapiece 1986). The distribution of surficial materials is as a result of the Keewatin (late Wisconsin) glaciation. Surficial materials in and near the Buffalo Lake basin consist of undulating and occasionally rolling glaciolacustrine clay and sandy glaciofluvial sediments, deposited over till. Further to the southeast, with greater relief, is the Bashaw Upland (elev 750 to $950 \mathrm{~m}$ ), where the primary landforms are hummocky till deposits, with some blanket till deposits over rolling bedrock (Wells and Bentz 1993, Bowser et al 1947). The approximate elevation close to the lakeshore is about $780 \mathrm{~m}$ above sea level.

According to Bowser et al (1947), the sandy loam soils along the north side of Buffalo Lake are quite variable, but generally contain coarse sand and usually some fine gravel. Soils are primarily black chernozems.

\subsubsection{Hydrography}

The basin and watershed characteristics of Rockeling Bay/Rider Lake are presented in Table 7. It is anticipated that the stabilization of water levels at Buffalo Lake will result in elimination of periodic natural flooding of adjacent Rockeling Bay/Rider Lake, and thus promote revegetation of beach nesting habitats (Prescott 1997). A proposed mitigation project would manage water levels to control shoreline vegetation around Rockeling Bay/ Rider Lake every 5 to 7 years, in order to rejuvenate piping plover nesting substrates. Specifically, the proposed piping plover habitat management project would allow for the filling of Rockeling Bay and Rider Lake to between $780.65 \mathrm{~m}$ and $780.85 \mathrm{~m}$ (A. Murphy memo, Dec. 20, 1995 to R. Wells).

Table 7. Rockeling Bay/Rider Lake basin and watershed characteristics (A. Murphy, pers. comm).

\begin{tabular}{l|l}
\hline \multicolumn{1}{c|}{ PARAMETER } & \multicolumn{1}{c}{ VALUE } \\
\hline & \multicolumn{1}{c}{ VA } \\
\hline Lake basin size at FSL* & $2.8 \mathrm{~km}^{2}$ \\
\hline Shoreline length & $12 \mathrm{~km}$ \\
\hline Modal annual water level decline & $220 \mathrm{~mm}$ \\
\hline Modal shoreline exposure (mid range) & $50 \mathrm{~m}$ \\
\hline Vertical substrate distribution (fr/FSL)*? & $0-1.5 \mathrm{~m}$ \\
\hline Maximum depth at FSL* & $2.5 \mathrm{~m}$ \\
\hline Habitat life expectancy and retum interval & 4 years $/ 5$ yrs (managed) \\
\hline Maximum habitat width & $200 \mathrm{~m}$ \\
\hline & \\
\hline Total watershed drainage area & $1440 \mathrm{~km}^{2}$ \\
\hline
\end{tabular}



*FSL - full supply level; Note: water levels are controlled in Buffalo Lake; FSL value taken from benchmark at control structure (A. Murphy, pers. comm., summary sheet)

\subsubsection{Water Quality}

Surface water chemistry data collected at a station on Rockeling Bay for 1980 and 1993 are given in Table 8. According to Wershler (1990), the freshening of Buffalo Lake may have an adverse effect on invertebrate populations which provide food for piping plover.

Table 8. Surface water chemistry data for Rockeling (Rockland) Bay, 1980 and 1993 (mg/l unless otherwise indicated) (NAQUADAT station, 27-41-20-W4; Alberta Environmental Prot., unpubl. data).

\begin{tabular}{l|c|c}
\hline \multicolumn{1}{c|}{ Parameter } & $\begin{array}{c}1980 \\
\text { (Sept) }\end{array}$ & $\begin{array}{r}1993 \\
\text { (Sept) }\end{array}$ \\
\hline Calcium & & \\
\hline Magnesium & 4.93 & 6 \\
\hline Sodium & 98.8 & 146 \\
\hline Chloride & 1450 & 3160 \\
\hline $\begin{array}{l}\text { Alkalinity } \\
\text { (total, } \mathrm{CaCO}_{3} \text { ) }\end{array}$ & 33 & 60.6 \\
\hline $\mathrm{HCO}_{3}$ & 2204 & 3580 \\
\hline $\mathrm{CO}_{3}$ & $\mathrm{n} / \mathrm{a}$ & 2145 \\
\hline Sulphate & $\mathrm{n} / \mathrm{a}$ & 828 \\
\hline Residue filterable & 1550 & 3400 \\
\hline $\begin{array}{l}\text { Specific conductance } \\
\text { (USIE/CM) }\end{array}$ & 4750 & 9982 \\
\hline & 5967 & 11560 \\
\hline pH (units) & 9.59 & 9.55 \\
\hline \\
n/a - data not available
\end{tabular}

\subsubsection{Vegetation}

Rockeling Bay/Rider Lake are included within the Central Parkland Natural Subregion. Upland vegetation is characterized by scattered groves of aspen interspersed with grassland or shrublands.

The vegetation along the nearshore areas of these waterbodies varies with the moisture regime and the coarseness of the substrate. In some seepage areas and isolated sections of the water bodies, there are patches of aquatic emergents, consisting predominantly of bulrush (Scirpus validus). Much of the shoreline is completely non-vegetated. Sparsely vegetated clayey shoreline areas have low rushes (Juncus spp.) and foxtail barley (Hordeum jubatum), while gravelly or sandy beach ridges are often heavily vegetated by foxtail barley (Hordeum jubatum), sometimes with gumweed (Grindelia squarrosa), sow thistle (Sonchus arvensis) and sweet clover (Melilotus $s p$.) There are scattered narrow bands of willow (Salix $s p$.) along the damper edges of the upper beach portion (Russ' field notes and photos, 1995).

Farther from the shoreline towards the upland areas, the vegetation cover consists primarily of grasses with scattered shrubs, primarily silverberry (Elaeagnus commutata), Canada buffaloberry (Shepherdia canadensis), and sparse balsam poplar (Populus balsamifera) trees. On the upland glacial till are grassy meadows interspersed with stands of balsam poplar and aspen trees. The woodlands have dense understories of buckbrush (Symphoricarpos occidentalis), rose (Rosa spp), and Canada buffaloberry, or red-osier dogwood (Cornus stolonifera) and willows in the damper areas. Silverberry is found often at the edges of aspen groves (Bird 1973, Russ' field notes and photos, 1995). 



\subsection{Piping Plover Populations}

The number of adult piping plovers observed during surveys conducted in the past 10 years has varied from 41 in 1989 to 0 in 1996 (Prescott 1997; Appendix A). In 1995 (the year of this habitat study), 13 adults were observed at Rockeling Bay, and 6 at Rider Lake (Table 4; Prescott 1997). One nest with eggs or young was recorded at each location in 1995 (ANHIC 1998).

\subsection{HABITAT INVENTORY RESULTS}

\subsection{Substrate Materials}

Gravelly substrate materials generally occur on these lakes as parallel shore beach bars, or as low points or spits when finer materials are removed by lakeshore wave action and wave induced, near-shore (littoral) currents.

The kind and amount of gravelly substrate materials present in the shoreline areas all three lakes are summarized by dominant map unit components in Table 9. Gravelly lacustrine units, LG and LGs units, dominate approximately 18,20 and 52 percent, respectively, of the Reflex Lake, Kilarney Lake and Rockeling Bay-Rider Lake shoreline areas. Of these, non-vegetated or nonvegetated and saline areas (LG and LGs units) total around 6 percent of the shoreline area for Reflex and Killarney shoreline areas but only 1.4 percent for Rockeling-Rider shoreline. Smaller amounts of sandy materials with fine lag surface gravel (LSg and LSgs units), 1.5, 2.8 and 0.5 percent, respectively, add to the available plover habitat at the three lakes. Note that the amount of suitable habitat indicated by shading is approximate because only dominant polygon components are considered.

At Reflex Lake, sandy eolian materials most of which (ESv, ES units) are sparsely or nonvegetated occupy around 40 ha (100acres), or 10.5 percent of the shoreline area. These sandy units, located on the lower to mid shoreline, are subject to continuing wind erosion with possible resulting deposition and burial of adjacent, more or less freshly exposed gravel bars (LG and LGs units) which are suitable plover nesting habitat.

Polygons with primary or secondary amounts of saline lacustrine sand with surface lag deposits of fine gravel (LSgs units) provide suitable nesting habitat at the eastern end of Reflex lake. Some of these units that have gravel-size particles of surface saline crust are also used as nesting habitat by the plovers.

Permanent seepage spring areas occupy nearly 3 percent of the Reflex shoreline area while a tiny amount of disturbed land is located on the upper shoreline along the northern side.

At Killarney Lake, gravelly surface materials comprise around 12 percent of the shoreline area. Of these, approximately 24ha (11 polygons) are non-vegetated (LG, LGs) and provide suitable plover nesting habitat. Sandy shoreline materials with lag surface gravel (LSg, LSgs) provide roughly 11 ha (10 polygons) of suitable shoreline habitat.

At the Rockeling Bay/Rider Lake shoreline area, non-vegetated gravelly substrate materials (LG, LGs) occupy approximately 6 ha in 14 polygons. These amount to less than 2 percent of the total shoreline area. Non-vegetated sandy materials with lag surface gravel cover just over 2 ha in 4 polygons, or 0.5 percent of the shoreline area. The gravelly sites then are relatively small and scattered, and may be quite vulnerable to disturbance, such as trampling by watering cattle. 



\subsection{Shoreline Area Soils}

Soil components of the shoreline habitat map units are classified according to the Canadian System of Soil Classification (Soil Classification Working Group 1998). The generalized soil sequence discussed here applies to shoreline areas of all three plover lakes.

Soil profile development and horizon differentiation increases with increasing distance away from the current lake edge. Rego Gleysols, with no surface mineral-organic (Ah) horizon, occur on recently exposed, non-vegetated areas immediately adjacent to the present lake edge. These soils are strongly gleyed and usually have a water table at or not far $(30 \mathrm{~cm}$ or less) from the surface.

At slightly higher, sparsely vegetated, less recently exposed levels, Rego Gleysols are replaced by Orthic Regosols and Rego Gleysols with thin, rudimentary Ah horizons. The depth to water table on these slightly dryer sites is generally greater than $30 \mathrm{~cm}$.

Again, at still slightly higher mid-shore sites with more or less continuous vegetation cover, Orthic Gleysols with thin Ah horizons occur as the dominant soils. Soils still exhibit strong gley features but depth to water table is generally greater than $50 \mathrm{~cm}$. At the same level, Rego Humic Gleysols (well-developed Ah horizons, $10 \mathrm{~cm}$ or more in thickness) occur under fully vegetated sites, possibly as a result of lateral seepage of oxygen and nutrient enriched water.

At mid and upper shoreline positions Rego and Calcareous Chernozemic subgroups, transitional between the Dark Brown and Black great groups are dominant under fully vegetated, upland grass or grass and shrub communities. A water table is generally absent above 1 meter.

\subsection{Habitat Suitability}

Habitat suitability/revegetation polygon ratings are shown for Reflex and the other two Parkland lakes in Figure 2. The ratings given in the bar graph consider the presence of secondary and tertiary map unit components as well as dominant components. Polygons with a Suitable primary component alone or with a Suitable primary and Unsuitable tertiary component (e.g. Lg//LSv) receive a Suitable rating. The unsuitable tertiary component is judged not to be a significant detriment to the overall suitability of the unit. See Table 2, page 4 for an essentially complete listing used to rate habitat suitability and rate of revegetation.

The Figure 2 graph shows Reflex and Killarney Lakes to have the highest proportion of SuitableNormal and Suitable-Slow rated shoreline area. Rockeling-Rider shoreline has the highest amount of marginally suitable habitat while small but significant areas of marginal habitat are also present at Reflex and Killarney Lakes.

Location and extent of suitable, marginal and unsuitable habitat and their rate of revegetation are displayed for each lake on the diagram maps in Appendix 3. These maps show Reflex and Killarney Lakes to have quite extensive sections of suitable habitat well distributed in close proximity to the current lake edge. At Rockeling Bay/Rider Lake, however, marginally suitable sites with a normal rate of revegetation are predominant while the few suitable sites (suitable slow) are scattered and small in extent. 
Table 9. Map Unit Summary of Substrate Materials for Parkland Plover Lakes (By dominant components)

\begin{tabular}{|c|c|c|c|c|c|c|c|c|}
\hline Lake & $\mathrm{Ha}$ & Map & Unit Area (ha & \# Polygons & \% Shrln & Eolian(\%) & Gravel(\%) & Sand/Silt(\%) \\
\hline Reflex & & ESt & 12.2 & 5 & 3.2 & & & \\
\hline T. Shoreline & 382.73 & ESv & 11.1 & 5 & 2.9 & & & . \\
\hline T. Water & 468.37 & ES & 16.8 & 3 & 4.4 & $40.2(10.5)$ & & \\
\hline \multirow[t]{13}{*}{ T. Area } & 851.10 & LES & 169 & 6 & 44 & & & \\
\hline & & LGt & 27.9 & 3 & 7.3 & & & \\
\hline & & LGu & 8.9 & 2 & 2.3 & & & \\
\hline & & LGv & 11.2 & 4 & 2.9 & & & \\
\hline & & LG. & 5.2 & 5 & 1.4 & & $70.0(18.3)$ & \\
\hline & & LSgs & 5.9 & 1 & 1.5 & & & \\
\hline & & LSs & 36.5 & 5 & 9.5 & & & \\
\hline & & LSt & 91.6 & 10 & 23.9 & & & \\
\hline & & LSu & 43.0 & 7 & 11.2 & & & \\
\hline & & LSv & 29.7 & 9 & 7.8 & & & \\
\hline & & LS & 55.1 & 11 & 14.4 & & & $206.6(68.4)$ \\
\hline & & $\overline{\mathrm{DL}}$ & 0.7 & 1 & 0.2 & & & \\
\hline & & SP & 10.2 & 4 & 2.7 & & & \\
\hline Killarney & & EGs & 1.2 & 1 & 0.3 & & & \\
\hline T. Shoreline & 407.89 & EGv & 8.3 & 4 & 2.0 & & & \\
\hline T. Water & 282.76 & EG & 4.3 & 1 & 1.0 & & & \\
\hline \multirow{20}{*}{ T. Area } & 691.48 & ESs & 4.5 & 3 & 1.1 & & & \\
\hline & & ESv & 26.1 & 11 & 6.4 & & & \\
\hline & & ES & 5.7 & 2 & 1.4 & $50.1(12.3)$ & & \\
\hline & & LEs & 81 & 6 & 20 & & & \\
\hline & & LGt & 20.8 & 7 & 5.1 & & & \\
\hline & & LGu & 18.7 & 5 & 4.6 & & & \\
\hline & & LGv & 18.7 & 12 & 4.6 & & & \\
\hline & & LE. & 15.8 & 5. & 3.9 & & $82.1(20.1)$ & \\
\hline & & LSgs & $4: 0$ & 2 & 1.0 & & & \\
\hline & & $\mathrm{LSg}$ & 7.2 & 8 & 1.8 & & & \\
\hline & & LSs & 164.4 & 20 & 40.3 & & & \\
\hline & & LSt & 4.7 & 3 & 1.2 & & & \\
\hline & & LSu & 4.7 & 3 & 1.1 & & & \\
\hline & & LSvs & 0.3 & 1 & 0.1 & & & \\
\hline & & LSv & 34.3 & 18 & 8.4 & & & \\
\hline & & LS & 52.7 & 3 & 12.9 & & & $272.3(66.8)$ \\
\hline & & $\mathrm{AE}$ & 1.9 & 2 & 0.5 & & & \\
\hline & & $\mathrm{DL}$ & 0.7 & 2 & 0.2 & & & \\
\hline & & SP & 0.8 & 3 & 0.2 & & & \\
\hline & & $z$ & 0.8 & 1 & & & & \\
\hline \multicolumn{2}{|c|}{ Rockeling-Rider } & LES & 5.8 & 13 & 1.4 & & & \\
\hline T. Shoreline & 421.23 & LGt & 5.1 & 2 & 1.2 & & & \\
\hline T. Water & 376.82 & LGu & 101.5 & 22 & 24.1 & & & \\
\hline \multirow{9}{*}{ T. Area } & 798.05 & LGv & 102.7 & 42 & 24.4 & & & \\
\hline & & LG & 0.1 & 1. & 0.0 & & & \\
\hline & & LSgs & 2.3 & 4. & 0.5 & & $217.4(51.6)$ & \\
\hline & & LSs & 39.9 & 18 & 9.5 & & & \\
\hline & & LSt & 28.4 & 15 & 6.7 & & & \\
\hline & & LSu & 42.8 & 8 & 10.2 & & & \\
\hline & & LSv & 72.3 & 39 & 17.2 & & & \\
\hline & & LS & 5.5 & 9 & 1.3 & & & $188.9(44.8)$ \\
\hline & & $\overline{\mathrm{AE}}$ & 14.9 & 18 & 3.5 & & & \\
\hline
\end{tabular}

$\mathrm{AE}$ - Aqatic emergents

DL - Disturbed land

SP - Seepage area

Z - Upland 



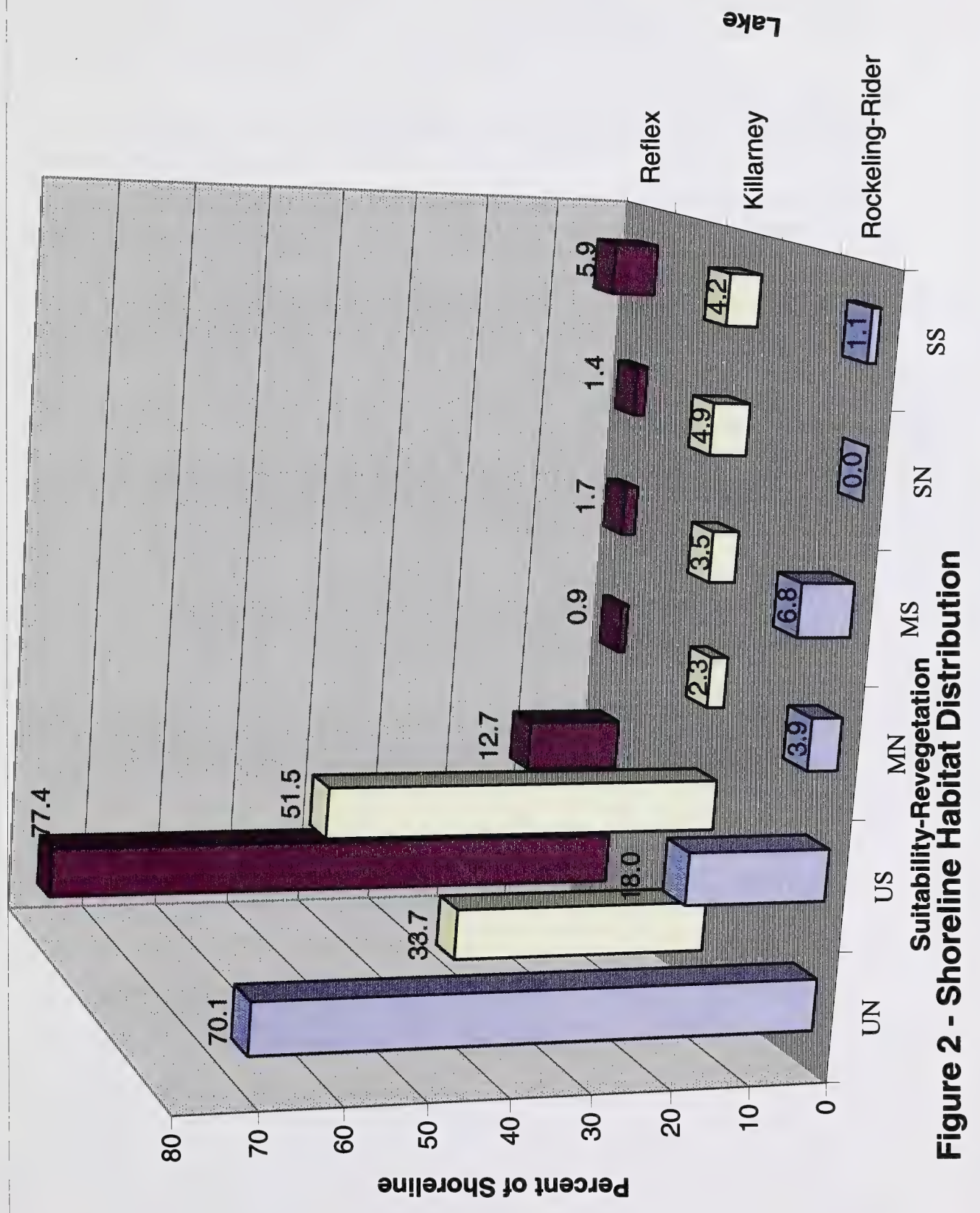





\subsection{SUMMARY AND CONCLUSIONS}

Inventory of plover habitat on these three lakes was done during the summer of 1995 and as a result, may not closely reflect shoreline area conditions present in 1999. Fluctuating water levels, vegetation encroachment, and wind erosion or deposition all interact dynamically to produce continually changing conditions in which the plovers may or may not thrive.

Land use activities by owners or lessees also play a significant role in this especially dynamic environment. Without enlightened management for example, the presence of grazing cattle during the active nesting period, May to July, can be deleterious to plover nesting success.

The results of the inventory suggest that Reflex Lake and Killarney Lake have the greatest potential to maintain suitable plover nesting habitat. High salinity at both these lakes should greatly reduce the rate of revegetation on suitable sites. Moreover, the presence of several permanent seepage springs serves to maintain a relatively constant water level at Reflex Lake. On the other hand, widely fluctuating water levels at Killarney Lake may mean that suitable sites are at times too distant to water to be utilized by nesting plovers.

Suitable nesting sites on the Rockeling Bay/Rider Lake shoreline area are of small extent and widely scattered. Quite a lot of trampling of these sites by watering cattle was observed during the field survey in the summer of 1995. Most of the non-vegetated, suitable gravelly habitat is present at slightly higher levels and is rated marginal because it is closely intermingled with more or less fully vegetated sites, cover that may increase access to nests by predators, such as foxes and coyotes. These marginal areas may have potential as habitat after future inundation and exposure. In addition, moderate to high salinity present at these sites should significantly slow their rate of revegetation. 



\subsection{LITERATURE CITED}

Achuff, P. 1994. Natural regions, subregions and natural history themes of Alberta. Prep. for Parks Services, Alberta Environ. Prot.

Alberta Environmental Protection. (no date). Unpubl. NAQUADAT (water quality) data. Environmental Assessment Div., Environ. Qual. Monitoring Branch. Edmonton.

ANHIC (Alberta Nature Heritage Information Centre database). 1998. Alberta Environ. Protection, Natural Reources Service. Edmonton.

Bayrock, L.A. 1967. Surficial geology of the Wainwright area (east half), Alberta. Alberta Research Council, Rep. 67-4. Edmonton.

Bird, C.D. 1973. Botany of Rochon Sands Provincial Park. Alberta Naturalist 3(3): 52-53.

Bjorge, R.R. and A.J. Murphy. 1997. The 1996 piping plover census in Alberta. Alberta Natural Resources Serv. Red Deer. Draft. 26 pp.

Bowser, W.E., R.L. Erdman, F.A. Wyatt and J.D. Newton. 1947. Soil survey of Peace Hills sheet. Univ. of Alberta Bull. No. 48. Alberta Soil Survey Report No. 14.

Carlson, V.A. and L.M. Topp. 1971. Bedrock topography of the Wainwright Map - Area NTS 73D, Alberta. Alberta Research Council.

COSEWIC. 1998. Canadian species at risk. Committee on the Status of Endangered Wildlife in Canada. April 1998. 22 pp.

Deboer, A. 1995. Piping plover nesting habitat lake water balances. Prep. by Surf. Water Assessment Branch. Proj. Rep. 5C/95-083. 23 pp.

Environment Canada. 1993. Canadian Climate Normals 1961 - 1990. Vol. 2, Prairie Provinces.

Govett, G.J. 1958. Solium sulphate deposits in Alberta. RCA Preliminary Report No. 58-5.

Green, R. 1972. Geological map of Alberta. Alberta Research Council, Edmonton.

Hackbarth, D.A. 1975. Hydrogeology of the Wainwright area, Alberta. Report 75-1, Alberta Research Council, Edmonton.

Haig, S. 1985. The status of the Piping Plover in Canada. Committee on the Status of Endangered Wildlife in Canada. Ottawa.

Haig, S. and L.W. Oring. 1985. Distribution and status of the piping plover throughout the annual cycle. J. Field Ornith. 56(4): 334-345.

Meijer, M. and E. Karpuk. (in prep.). Dillberry Lake Provincial Park Biophysical Inventory. Prep. by Alberta Resource Data Div. for Alberta Natural Resources Service, Rimbey.

Moss, E.H. 1932. The poplar association and related vegetation of central Alberta. J. Ecol. 20: $380-415$.

Murphy, A. Personal communication. May 31, 1996. memo to Russ Wells, subject Killarney Lake. 

Nature Conservancy of Canada. 1990. Reflex Lake, biophysical overview. Unpubl. Rep. Nature Conservancy. Calgary.

Pettapiece, W.W. 1986. Physiographic subdivision of Alberta. Agric. Canada, Alberta Inst. of Pedology. Edmonton.

Prescott, D.R. 1997. Status of the Piping Plover (Charadrius melodus) in Alberta. Alberta Environ. Protection, Wildlife Manage. Div., Wildlife Status Rep. No. 1. Edmonton. 19 pp.

Renewable Resources Consulting Services Ltd. 1974. Dillberry Lake resource inventory and analysis. Unpubl. rep. prep. for Alberta Recreation and Parks. Edmonton. 302 pp.

Semenchuk. G. 1992. The Atlas of Breeding Birds of Alberta. Federation of Alberta Naturalists. Edmonton.

Soil Classification Working Group. 1998. The Canadian System of Soil Classification. $3^{\text {rd }}$ ed. Research Branch, Agriculture and Agri-Food Canada. Publication 1646. 187pp.

Strong, W.L. and J.M. Thompson. 1995. Ecodistricts of Alberta: summary of biophysical attributes. Prep. for Resource Data Division, Alberta Environ. Protection, Edmonton. 92 pp plus maps.

Thorpe, J. and R. Godwin. 1993. Vegetation survey of the Manito Sand Hills. Publ. E-2550-1-E93, Saskatchewan Research Council, Applied Plant Ecology Section. 100 pp.

Wallis, C. 1987. Critical, threatened and endangered habitats in Alberta. Pp. 49-63 in Endangered Species in the Prairie Provinces. Prov. Museum of Alberta. Natural History Occ. Paper No. 9.

Wallis, C. 1990. Reconnaissance survey of saline wetlands and springs in the Grassland Parkland Region of eastern Alberta. Prep. for World Wildlife Fund Canada, Prairie for Tomorrow, Edmonton. 105 pp.

Wells, R.E. and J. A. Bentz. 1993. Integrated resource inventory of the Red Deer River corridor study area. Alberta Environ. Protection, Resource Info. Div., Edmonton.

Wells, R.E. and B.J. Cornish. 1999. Piping plover habitat classification at selected

Grassland Region lakes. Alberta Environment, Resource Data Div. Edmonton. 34pp + maps.

Wells, R.E. and M. Lindberg. 1991. Little Fish Lake piping plover habitat classification. Alberta Forestry, Lands and Wildlife, Resource Information Branch. Edmonton. 35 pp.

Wershler, C.R. and C. Wallis. 1986. Status of the Piping Plover in Alberta. Prep. by Sweetgrass Consultants for World Wildlife Fund, Canadian Wildlife Service and Alberta Fish and Wildlife.

Wershler, C.R. 1988. Monitoring of piping plovers, habitat and land use at Little Fish Lake, Alberta. Prep. for Alberta Recr. and Parks, World Wildlife Fund, Alta Fish and Wildl. and Can. Wildl. Serv.

Wershler, C.R. 1990. Management plan for the piping plover in Alberta. Prep. for Alberta Fish and Wildlife, World Wildlife Fund Canada and Prairie for Tomorrow.

Wershler, C.R. 1992. An analysis of piping plover management concerns in Alberta. Prep. for North American Waterfowl Management Plan, Alberta Fish and Wildlife Div. 

Wyatt, F.A., J.D. Newton, W.E. Bowser and W. Odynsky. 1944. Soil survey of Wainwright and Vermilion sheets. Bull. No. 13, Univ. of Alberta, Edmonton. 

APPENDIX A

ADULT PIPING PLOVER AT FOUR PARKLAND LAKES, 1989 - 1996 

APPENDIX A. Adult piping plovers at four parkland lakes in Alberta between 1989 and 1996 (summarized in Prescott 1997).

\begin{tabular}{|c|c|c|c|c|c|c|c|c|c|c|c|}
\hline \multirow[t]{2}{*}{ LAKE } & \multicolumn{11}{|c|}{ YEAR } \\
\hline & 1986 & 1987 & 1988 & 1989 & 1990 & 1991 & 1992 & 1993 & 1994 & 1995 & 1996 \\
\hline $\begin{array}{l}\text { Killarney } \\
\text { Lk. }\end{array}$ & $n / a$ & $\mathrm{n} / \mathrm{a}$ & $n / a$ & $8-10$ & $\mathrm{n} / \mathrm{a}$ & 22 & $\mathrm{n} / \mathrm{a}$ & 29 & 48 & 40 & 25 \\
\hline $\begin{array}{l}\text { West } \\
\text { Reflex Lk. }\end{array}$ & $46+$ & $35+$ & $\mathrm{n} / \mathrm{a}$ & 20 & 21 & 12 & 11 & 16 & 28 & 37 & 19 \\
\hline $\begin{array}{l}\text { Rockeling } \\
\text { Bay }\end{array}$ & 18 & $n / a$ & $\mathrm{n} / \mathrm{a}$ & 30 & 22 & 6 & 9 & 12 & 17 & 13 & 0 \\
\hline $\begin{array}{l}\text { Rider } \\
\text { Lake }\end{array}$ & 15 & $\mathrm{n} / \mathrm{a}$ & $n / a$ & 11 & 17 & 7 & 16 & 7 & 12 & 6 & 0 \\
\hline
\end{tabular}

n/a - data not available 

APPENDIX B

DIAGRAM MAPS FOR PLOVER HABITAT SUITABILITY AND REVEGETATION RATE 



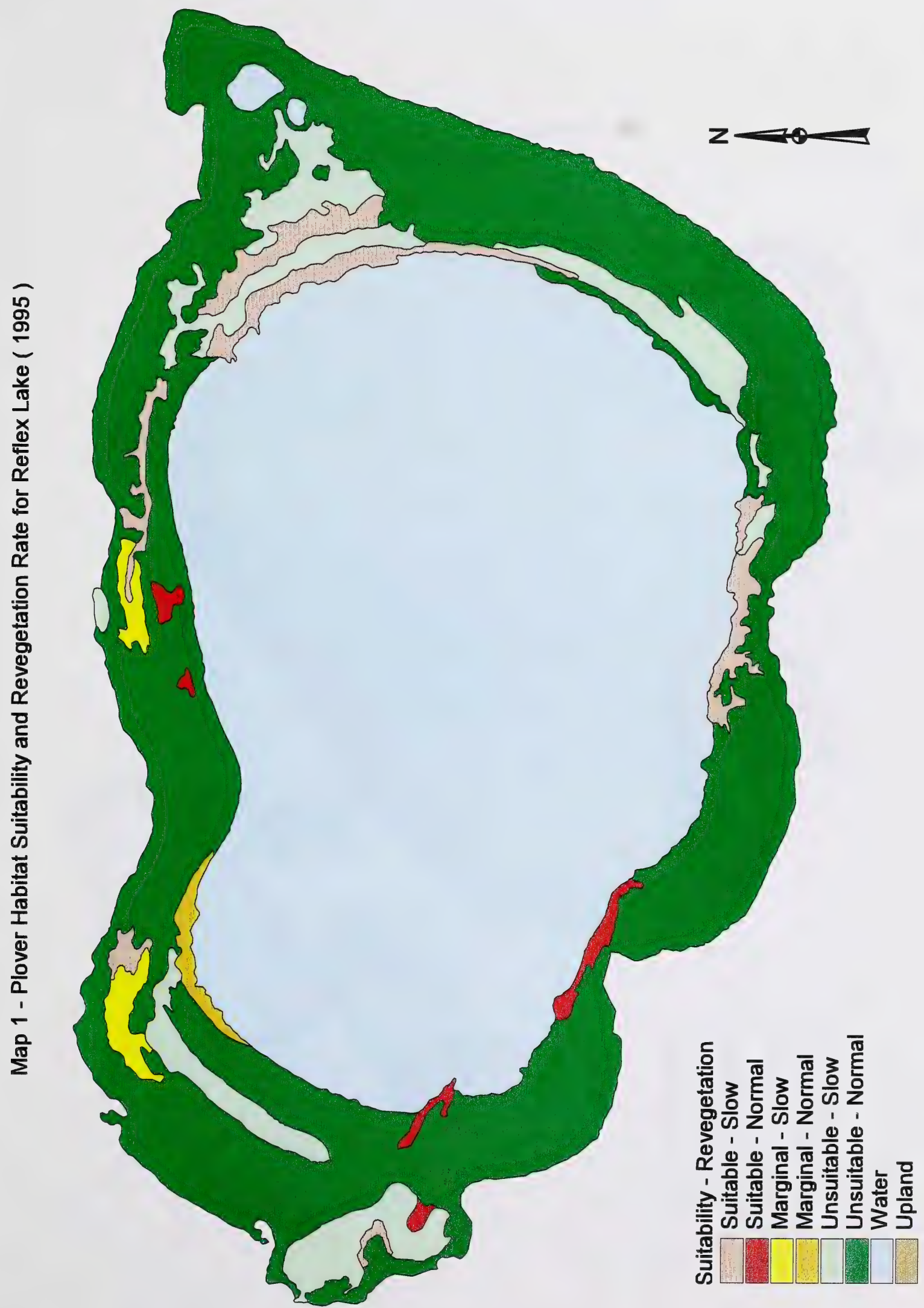




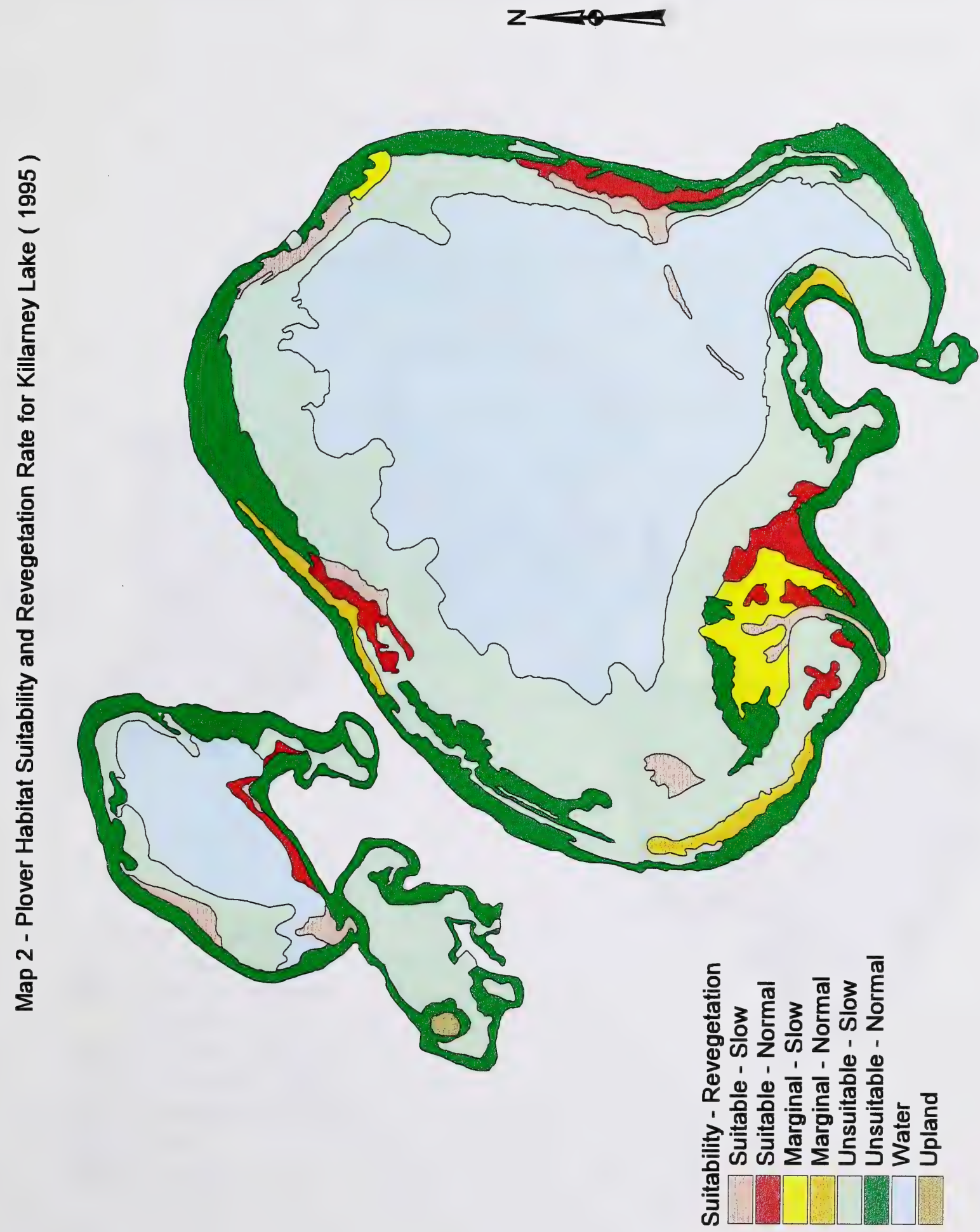

Map 3 - Plover Habitat Suitability and Revegetation Rate for Rockeling Bay / Rider Lake ( 1995 )

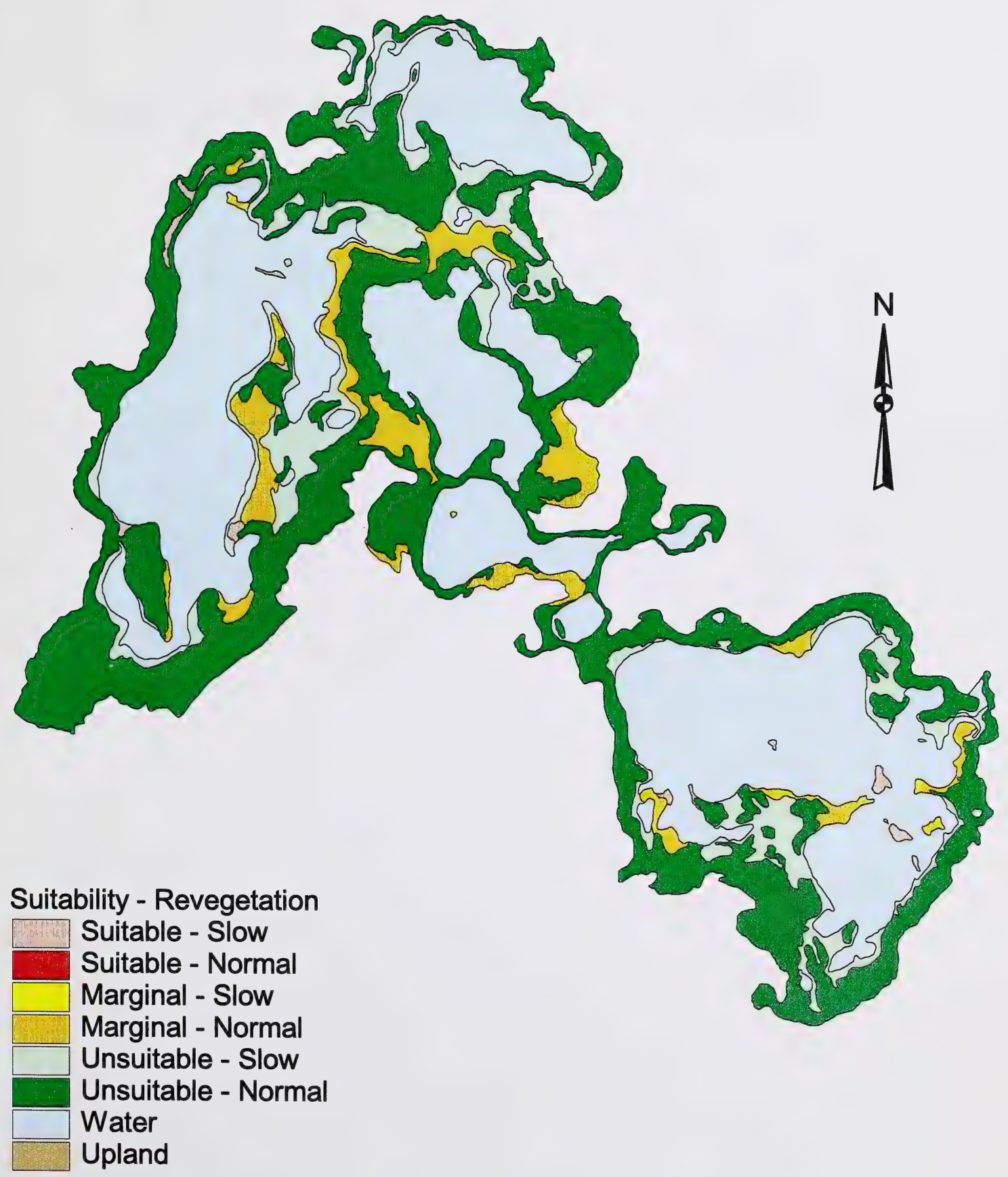





\section{APPENDIX C}

GENERALALIZED PIPING PLOVER HABITAT CLASSIFICATION MAP LEGEND 



\begin{tabular}{|c|c|c|c|c|c|c|c|}
\hline 言 & $D$ & $\supset$ & $n$ & $n$ & $D$ & $D$ & $D$ \\
\hline 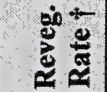 & $z$ & $n$ & $z$ & $n$ & $z$ & $z$ & $\infty$ \\
\hline 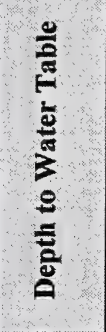 & 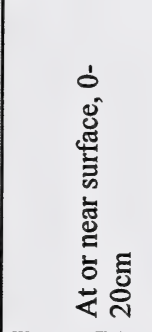 & 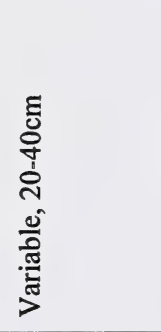 & 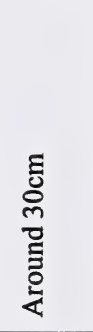 & 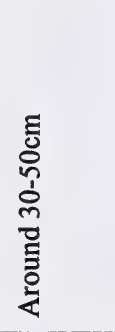 & 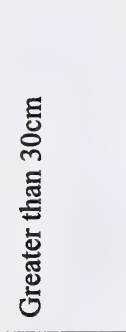 & 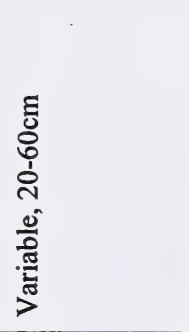 & 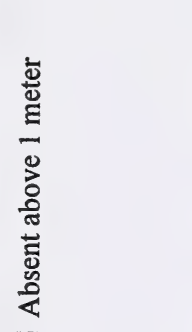 \\
\hline 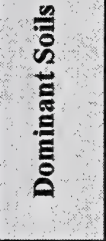 & 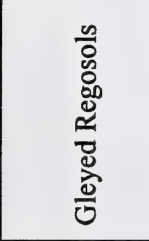 & 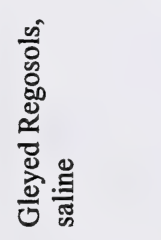 & 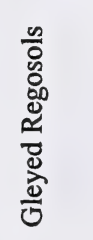 & 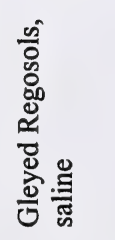 & 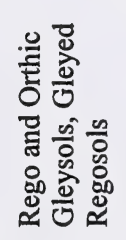 & 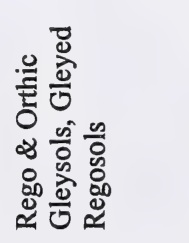 & 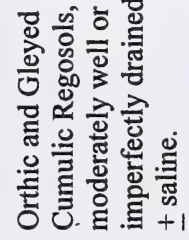 \\
\hline 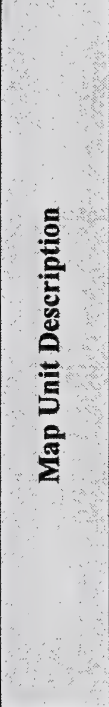 & 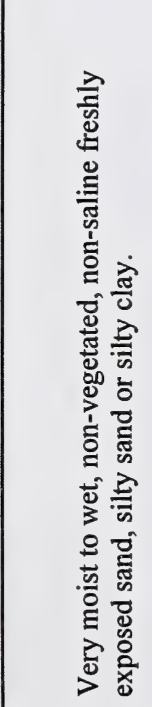 & 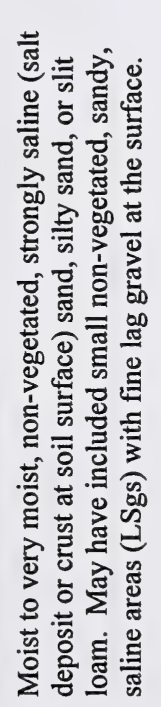 & 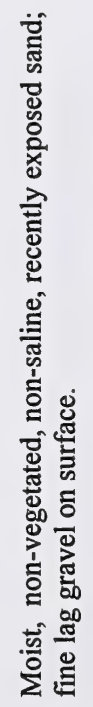 & 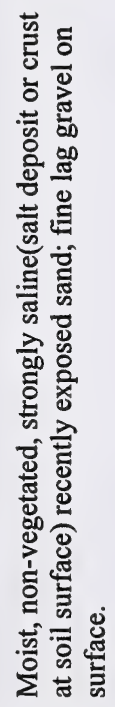 & 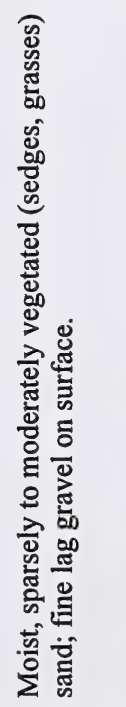 & 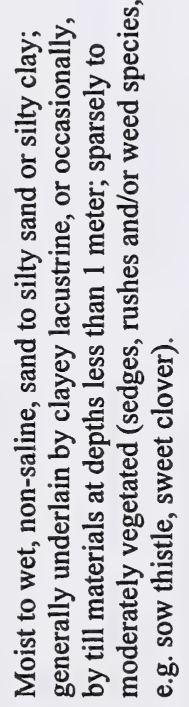 & 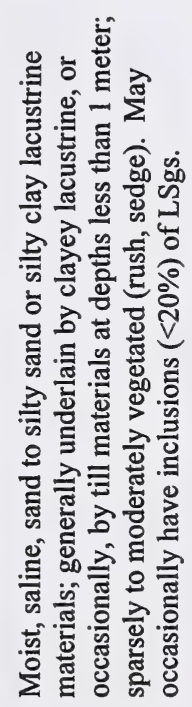 \\
\hline 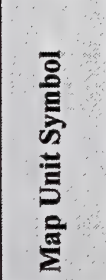 & 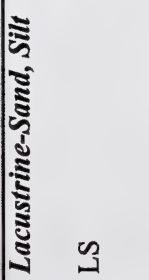 & బึ & ஸे & 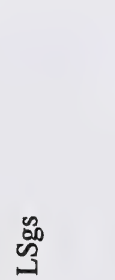 & $\begin{array}{l}\overrightarrow{0} \\
\text { బิ }\end{array}$ & 岕 & 岂 \\
\hline
\end{tabular}





\begin{tabular}{|c|c|c|c|c|c|c|c|c|}
\hline 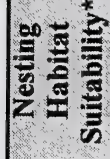 & D & D & & $\infty$ & $\infty$ & $\Sigma$ & D & $p$ \\
\hline : & $z$ & $z$ & & $z$ & $\infty$ & $z$ & $z$ & $z$ \\
\hline 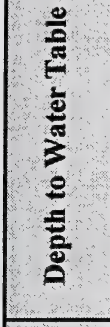 & 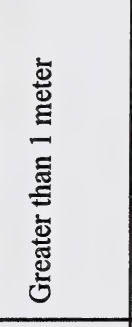 & 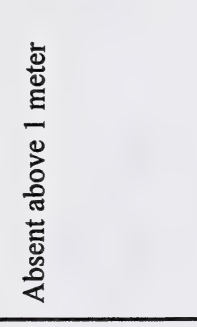 & & 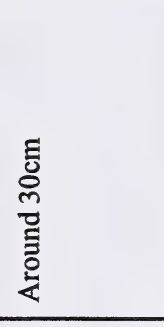 & $\begin{array}{l}5 \\
5 \\
0 \\
0 \\
0 \\
0 \\
0 \\
0 \\
0 \\
0 \\
\end{array}$ & 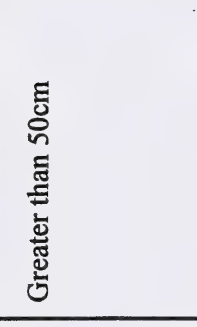 & 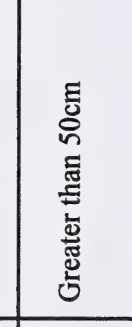 & 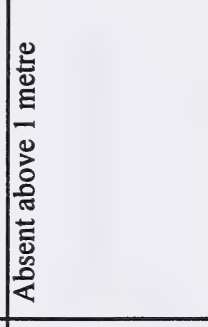 \\
\hline 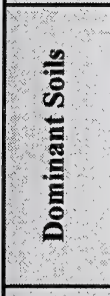 & 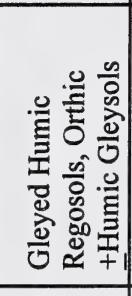 & 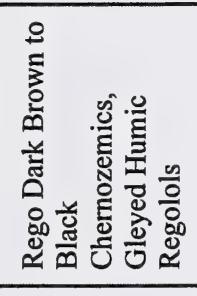 & & 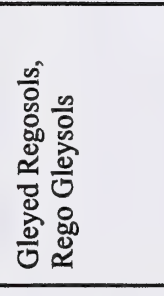 & 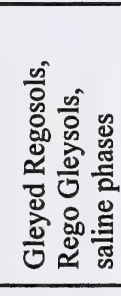 & 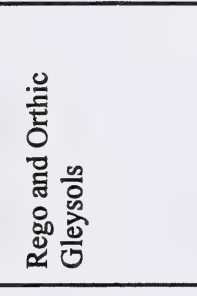 & 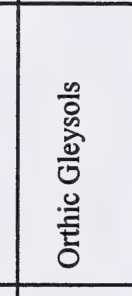 & 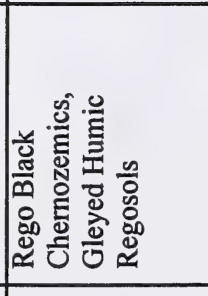 \\
\hline 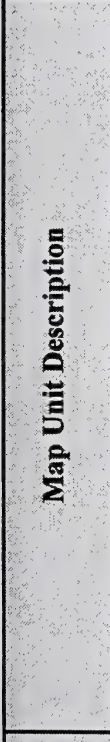 & 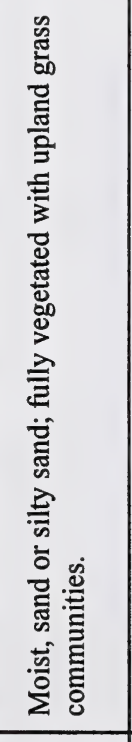 & 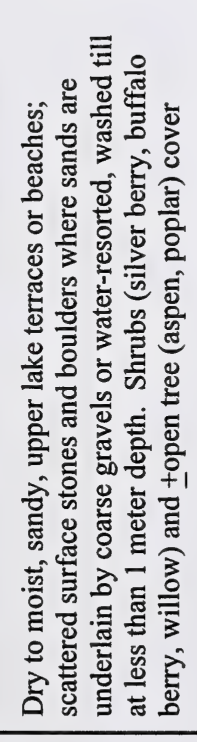 & & 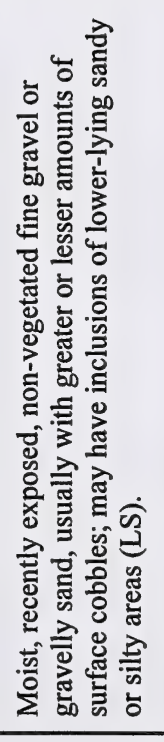 & 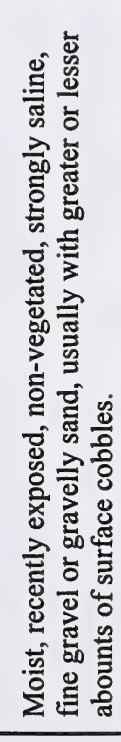 & 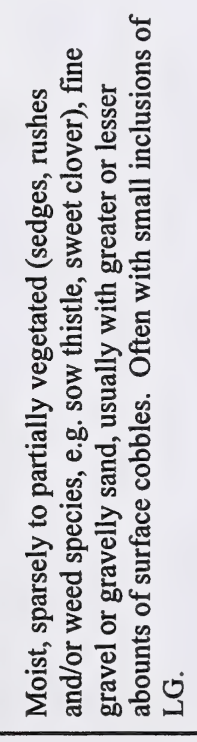 & 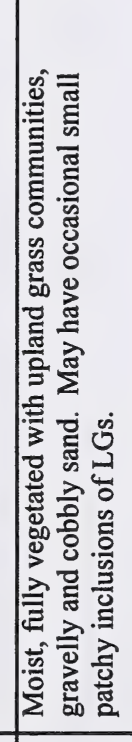 & 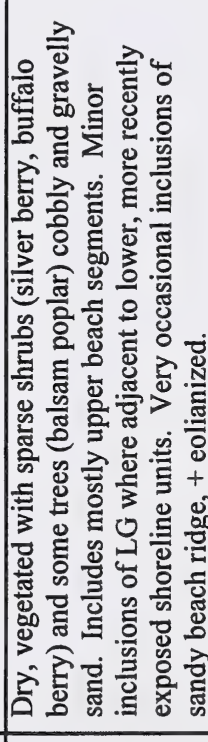 \\
\hline 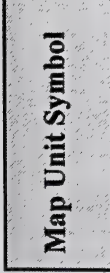 & $\overrightarrow{\underline{s}}$ & $\overrightarrow{3}$ & & 0 & $\stackrel{g}{3}$ & తృ & 䛎 & J \\
\hline
\end{tabular}






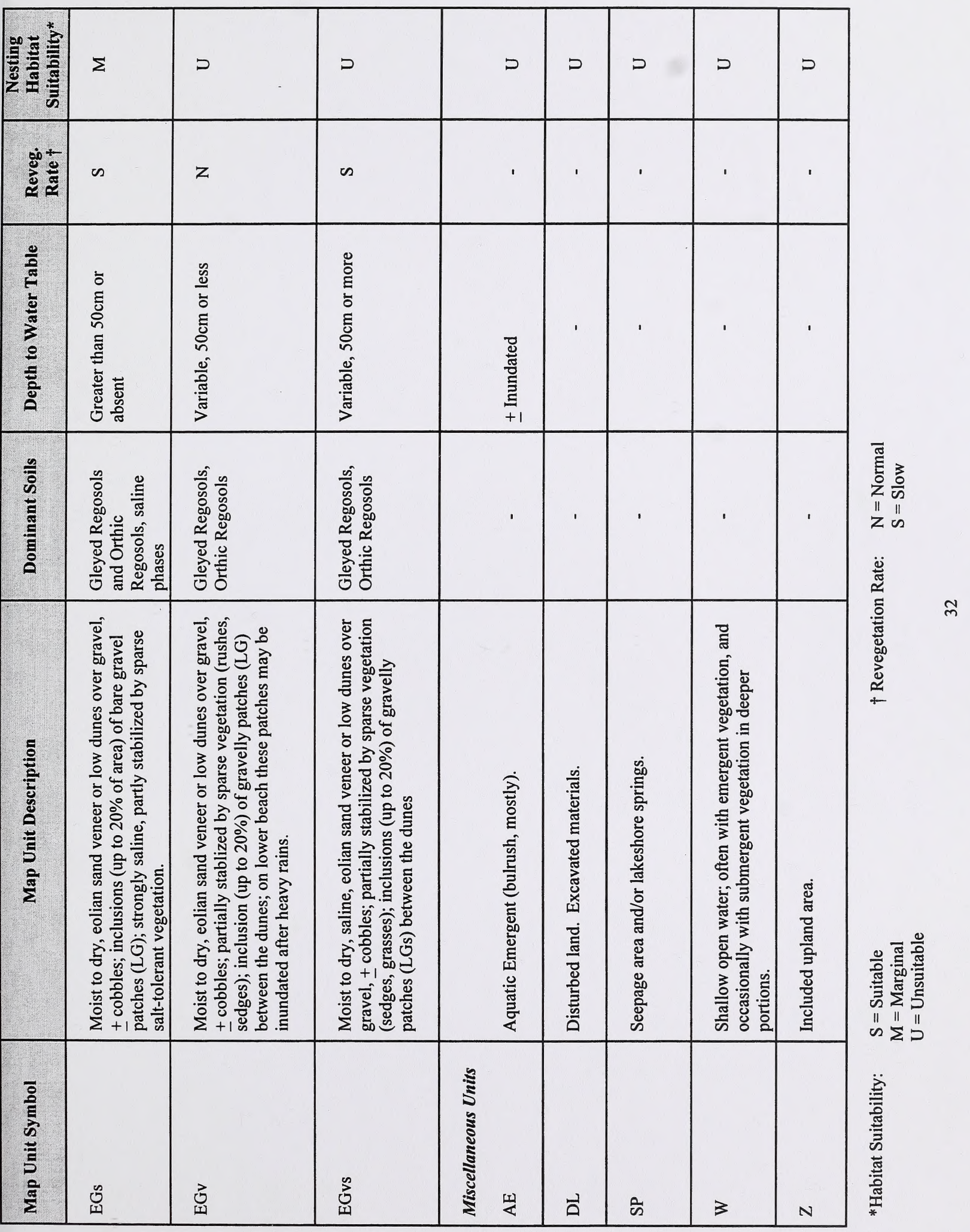



National Library of Canada

Bibliothèque nationale du Canada

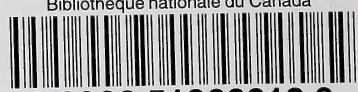
33286519666180 